\title{
THE ELECTRTC LIGHTING OF EDINBURGH.
}

By Mr. HENRY R. J. BURSTALL, of LondoN.

The Electric Lighting of Edinburgh, as is also the case in many of the most important towns in England and Scotland, is in the hands of the Corporation; and was finally decided on late in 1893, when the work of designing and superintending the whole scheme for public and private supply was entrusted to Professor Kennedy. Work was commenced at the station and in the streets in May 1894, and the station was opened for the continuous supply of electrical energy on 11th April 1895, the exceptionally severe winter having serionsly delayed the progress of the station buildings.

Districts.-From the electrical point of view the city of Edinburgh may be said to consist of two districts, differing from each other both in character, and in their positions relative to the centre of the city, Fig. 1, Plate 140. The older part of the city by the Castle, and the district north of Princes Street, include the greater part of the business premises, together with a residential district in which the houses are large and closely built, and where the demand for current may be expected to be great. The district to the south and east of the central portion is either residential or of such a character that the demand for current can never be as large as that in the northern and central district. The residential part of this district contains many houses which stand detached from one another, thus diminishing considerably the possible number of lamps in proportion to the frontage. Having regard to the different districts to be served, and taking into acconnt all the local circumstances, it was decided, after comparison of the various systems of supply and distribution which could be used, to adopt a low-tension three-wire system for the 
central and northern district, and an alternating-current high-tension system for the southern and eastern district, both systems being worked from one central station and under the same control and management. A good site was found for the Central Station between the Caledonian Railway and Dewar Place. The foundation here is rock; and the station being on the railway, coal is brought direct into the boiler house in the railway trucks at a minimum of expense. The position of the site is such that, while being fairly central, it is in a neighbourhood where there is little chance of complaint as to nuisance, real or otherwise.

\section{Station.}

The building, which is a handsome brick erection with brown stone frontages to Dewar Place and Torphichen Street, is from the designs of Mr. J. Cooper, the Burgh Engineer, and was erected under his superintendence. The site is roughly triangular; the boiler house occupies nearly the whole of the north side, and the two engine rooms are parallel to and south of it; the general offices occupy the extreme south of the site, and are large enough for the accommodation of the whole of the clerical staff, as well as for the resident engineer and his assistants. Above the boiler room are the workshops; and the floor above the western end of the engine rooms is used for the battery room, store room, and meter store and testing rooms. The eastern part of the engine room is covered with a light iron roof, with ample provision for light and ventilation. The boiler room is covered with a concrete floor, which will ultimately be used as a coal store. There is ample space in the buildings at present erected for considerable extensions without any extra outlay beyond the foundations for new engines and boilers.

Boiler House.-The boiler house, Figs. 2 to 4, Plates 141 to 143, is 152 feet long by 46 feet wide, occupying nearly the whole of the north side of the site. It is designed to contain seventeen boilers, Fig. 12, Plate 150, of which at present only the six at the west end are in place. The main flue runs along the centre under the stoking 
floor into the chimney, which is placed in the middle of the length of the house, and is 8 feet square inside and 160 feet high, being lined with fire-brick for a height of 60 feet. The side flues from each boiler enter the main flue at a slight angle, and each flue is fitted with a butterfly damper; a damper is also placed in the main flue close to the chimney.

The boilers are of the dry-backed marine type, Plates 142-3, each $10 \frac{1}{4}$ feet mean diameter and 12 feet long, with two Purves flues, $3 \frac{1}{4}$ feet inside diameter, and 166 tubes of 3 inches internal diameter. The boilers are of steel, with wrought-iron tubes, and have been built in accordance with Board of Trade rules for a working pressure of $160 \mathrm{lbs}$. per square inch above atmosphere. They are fitted with the usual mountings, and have duplicate feed checkvalves.

On the top of the boilers are fitted superheaters SS, Plates 141-3, each consisting of two nests of tubes enclosed between the top of the boiler shell and a fire-brick casing above, with a space left in the centre for the steam-valves, safety-valve, \&c. Each superheater consists of twenty-six vertical flat coils of wrought-iron tube $1 \frac{1}{2}$ inch diameter, running from a large cast-iron pipe at the back of the boiler to a similar pipe at the front, all joints being outside and protected from the action of the gases. The steam cireulates from a standpipe on the boiler to the back leading pipe, through the superheating tubes to the cast-iron pipe at the front, and thence to the main steam-pipe; proper valves are arranged so that the superheater can be entirely shut off and the steam be taken direct to the main steam-pipe. Each superheater is fitted with a safety-valve and draining cocks. The superheater coils are readily accessible for cleaning and examination by doors at the front and by movable plates at the top; or if necessary they can be lifted bodily away from the boiler. The course of the furnace gases is from the furnace to a brick combustion-chamber at the back of the boiler, through the boiler tubes to a wrought-iron smoke-box at the front, thence up and along the top of the boiler, past the superheater tubes to the back, and there down each side to a centre flue under the bottom of the boiler. A damper is provided, by which the gases can be sent direct 
to the sides of the boiler without passing the superheater tubes. Sinclair's mechanical stokers are fitted to each boiler, and are worked from two lines of shafting, which are carried by the columns of the boiler house and driven by an electric motor.

Steam is taken from each boiler through a standpipe, with valves to the superheaters; and from the latter through a large copper bend to the main steam-pipe, which forms a complete ring round the present boilers. This ring joins the engine-room main at two points; and is provided with valves, so that the failure of any one pipe will put only the corresponding boiler out of use. Drain-valves are placed wherever water may accumulate, and are all connected to a steam-trap which returns the condensed water to the feed-tank.

The pump room is opposite the chimney, and is entirely closed in, Plate 141. It contains at present one duplex steam-pump $D$ and two three-throw pumps PP driven electrically; each pump has a maximum capacity of 4,500 gallons per hour. The electrically driven pumps are specially designed to run with a large range of speed; and for this purpose can be connected with either the 230-volt or the 115-volt mains. The steam-pump has its steam supply connected with two points of the main steam-pipe, and its exhaust is connected with the feed-heater. Each feed-pump has an independent suction from the feed-tank, and two independent deliveries into two separate lines of pipes, each of which can be connected with either range of the two duplicate rings of feed-pipes, either through the feed-heater or direct. The duplicate rings of feed-pipes are carried round the stoke-hold in chases in front of the boilers; and each boiler is connected with both rings of pipes by separate feed check-valves delivering into a common internal pipe. A Kennedy water-meter $K$ is connected with one range of feed-pipes, so that the whole of the water going to the boilers can be measured. In the pump room is placed the electric motor M for driving the mechanical stokers with its countershaft; and there is ample space for more pumps when they are required.

Under the pump room is the feed-tank, which communicates with a large storage tank at the end of the boiler house; another feedtank is also provided under the workmon's room, so that there is an 
ample reserve of water in case of accident to the water supply. A siding from the Caledonian Railway runs into the boiler house, and the coal brought in the railway trucks is at present stored in the east end of the boiler house; on the station being extended, the coal will be, stored over the boiler house, and let down through shoots to the mechanical stokers. In designing the plant at present in the boiler house, provision for extensions has been kept in mind; and the arrangements are such that new plant can be added at any time, without interfering in any way with the working of that already in use.

Engine Rooms.-The engine rcoms, Plates 143 to 147 , are each about 102 feet long, and are side by side, Fig. 12, Plate 150, forming really one room divided by a line of columns which carry the roofs and the beams for the travelling cranes. The engine room next the boiler house is reserved for the low-tension plant, and is $46 \frac{1}{2}$ feet wide; the other contains the high-tension plant, and is $41_{2}^{\frac{1}{2}}$ feet wide. A platform $F$, raised 4 feet above the engine-room floor-level, runs the whole way across the west end of both enginerooms; and on this are placed the switchboards and regulating gear for both the low and high-tension systems, as well as the office of the engineer on watch.

Low-Tension Engine-Room.-The machinery at prosent in the low-tension engine-room, Plates 143 to 147 , consists of eight engines, four of 100 I.H.P., two of 250 I.H.P., and two of 360 I.H.P., with their dynamos; and provision is made for eight more engines of 360 I.H.P. in the future. All are Willans central-ralve engines driving their dynamos direct. All the dynamos are two-pole shuntwound machines with drum armatures, wound to give 270 volts, with the exception of two which are driven by two 100-I.H.P. engines; these two are wound to give 135 volts, being used as balancing machines on the three-wire system.

The steam-piping forms, with part of the boiler-house ring, a complete ring round the low-tension engine-room, Plates 141 and 146 , and is connected with the boiler-honse ring at two points. The main ring is 8 inches internal diameter throughout: the straight 
lengths are of steel, with thick flanges screwed and brazed on; the tee pieces and valve-boxes are of cast-iron, and the bends of copper with steel flanges. All bends are of large radius, and no expansion joints are used or required. The engines are erected in pairs, and are connected with the main ring by two long copper bends, Plates 143-4 and 146-7; in the main ring a valve is placed between the branches to the two pipes, with a cross-over pipe and valve at the engines, so arranged that the engines can take their steam from either side of the valve in the main ring. The pipes are slung by long rods $L$ from brackets fixed on the walls or columns, so as to allow free movement.

In every section of the main ring are placed two drain-valves, one connected with a drain ring, which is common to half the drains, and is connected with a large steam-trap, whereby all condensed water is returned to the feed tank. The other drain-valve is connected direct to the exhaust pipe, and is used only on emergency, or when the steam is entirely shut off from that section of the pipes. The separators on all the engines are connected to a second steam-trap, which returns the water collected to the feed tank; the drains from the cylinders, \&c., are connected to the exhaust pipe. The whole of the steam-pipes and valve-boxes, as well as the drain-pipes up the steam traps, are covered with non-conducting composition, and special non-conducting covers are fitted on all the flanges; in fact every attempt has been made to reduce the loss by condensation in the steam-pipes, which forms so considerable an item in the losses that occur in centralstation work.

All the engines are fitted with cooling pipes in the crank chambers, to which the water is carried in a line of pipe round the engine foundation-block, and taken thence to the feed-tank by a second line. Each engine is fitted with a valve on the exhanst; the exhaust steam is led by a copper bend into the main exhaust-pipe, which is carried in chases in the engine foundation-block and along the void between the block and the walls. The main exhaust-pipes are of cast-iron, and are led, through a Berryman feed-heater $H$ in the boiler house, to the chimney, Plates 141 and 142. Only one heater is fixed at present; but provision is made for three more 
when required. From the heater the exhaust steam is carried up to the top of the chimney by a vertical cast-iron pipe 21 inches diameter. Valves are provided so that the exhaust steam can be carried direct to the vertical exhaust-pipe, without going through the heater.

The whole of the machinery stands on a concrete foundationblock B, $7 \frac{1}{2}$ feet thick, Plates 143 to 147 , which is separate from the foundations of the walls. A void 3 feet wide is left at each side of the block, which is also stopped some distance in front of the switchboard platform $F$, thus forming a large chamber at the west end of the two engine-rooms for the connections, \&c. An 8-ton travelling crane C, Plate 147, running the whole length of the engine block, is provided in each engine-room, for convenience in overhauling, \&c. These cranes are worked entirely from below by means of ropes.

Leads.-The main leads from the dynamos are drawn through curved wrought-iron pipes let in to the concrete, into chases $J J$ in the centre of the engine foundation-block, Plates 143 to 146, along which they are carried to the chamber under the switchboard platform $F$. The leads from the field winding of the machines are also carried in the same manner to their regulating resistances, which are placed under the platform; the switches for these resistances are fixed upon the handrail on the platform, in front of the switchboard, the leads from the resistances being brought up through the posts of the handrail.

Switchboard and Conductors.-The switchboard, and the whole of the apparatus for regulating the dynamos and batteries, and for the distribution of the current, are placed on the platform, Plates 143-4 and 146-7, and are directly under the eye of the engineer in charge. The switchboard consists of seven slate panels, each about 7 feet high ; and stands 4 feet from the west wall of the engine room, thus allowing ample room to do any work on the connections \&c. at the back. The instruments and gear for regulating the battery are mostly placed on the centre panel, and those for the switehing and manipulation of the dynamos and feeders are on the six onter slates 
the connections for the positive side of the system are on the left hand, those for the negative on the right, and the middle wire is connected on the centre panel.

The arrangement of the switchboard and conductors is as follows. The feeders enter the building at a cellar under the pavement on the west side, and are brought along the wall under the platform in the form of heavy copper rods, which are carried on insulators, and pass up through the floor to their respective terminals at the back of the switchboard, and are attached to the terminals at the top of the board by cones and nuts. They are connected, through a duplex fuse and an ampère meter, to heavy vertical copper bars on the front of the slates, each bar having three holes in it, through which plugs can be inserted. The leads from the dynamos are carried in the form of insulated cable to their respective terminals at the back of the board, near the bottom; and through fuses, automatic switches, and ampère meters, are connected to vertical copper bars fixed to the front of the slates, similar and parallel to the feeder bars. The automatic switehes are so constructed that the switch, after being closed by hand, is held in place as long as the current flowing through it exceeds from 15 to 20 ampères; should it fall below this, a trigger is released and the switch is automatically opened, thus breaking the circuit and preventing damage if a machine should fail from any cause. Three heavy copper "omnibus" bars are fixed horizontally at the back of the three outer slates on each side, and are capable of being connected to any of the feeder and dynamo bars of that side by means of heavy copper plugs, which are inserted through holes in the vertical bars and slates, and scrow into the cmnibus bars at the back, the contact being made on the front bars by a faced collar. The feeders under ordinary circumstances are all connected to the top omnibus bar, and are all in parallel. In order to connect any dynamo to the feeders, plugs aro screwed into the top holes of the vertical bars corresponding with that dynamo, the brushes of the machine are put down upon the commutator, and the stop valve of the engine is fully opened so that the engine is running on its governor; the switchboard attendant regulates the electromotive 
force of the machine until it is equal to that shown on the voltmeter between the top bars, and then closes the automatic switch, putting load on the dynamo by taking resistance out of its field cirenit. During the whole time the machine is on circuit it is regulated by the switchboard attendant, the engine running on its governor with the stop valve full open; the engine-driver has to attend only to the running of the engines and dynamos. For the sake of economy however, the engines are run somewhat slower at low loads than at full load; after about three-quarters of the full load has been reached, the setting of the governor is altered, and the engine run at full speed. In order to take the machine off circuit, resistance is put into the field circuit until the current falls so low that the automatic switch opens; the driver then lifts the brushes out of contact, and shuts down the engine.

Balancing Machines.-The foregoing description applies only to the high-volt machines; the connections for the balancing machines are somewhat different, Plate 146. The leads for each of these dynamos are connected-through fuses, ampère meters, and automatic switches, as for the high-volt machines-to two contacts of a doublepole switch on the centre panel; and can be connected alternatively with two of three contacts, one of which is connected to the middle wire and the other two to dynamo bars on the positive and negative sides of the switchboard respentively. Thus each balancing machine can be put between the middle wire and either the positive or the negative side of the switchboard. These machines are run in exactly the same manner as the high-volt machines, and the whole of their regulation is done from the switch platform.

In the cireuit of each dynamo is a registering ampère-hour meter, from which are taken readings whenever the machine is started and stopped; and the station records of the units generated are made up from these readings. Volt meters are provided, which can be connected to the terminals of each dynamo by means of multipolar switches; other volt meters are also connected, so as to show the electromotive force between any of the omnibus bars on the positive and negative sides, and also between the omnibus bars and 
the middle wire. A pair of volt meters are fixed on the upper part of the centre slate, and are connected through multipolar switches, so as to show the pressure between the middle wire and the positive and negative wires respectively at any feeding point on the system; and for this purpose light wires are brought back from the foeding points. The switchboard attendant is thus able to know directly the electromotive force on the distributing mains; and regulates the electromotive force at the switchboard so as to keep this constant.

The two lower horizontal omnibus bars can be connected by plugs to any feeder or any dynamo; by this means it is possible to run any feeder or feeders at a higher or lower electromotive force than the others, should occasion arise. The same two bars are also used for testing, and for the introduction of standard instruments into the circuit of any feeder, dynamo or battery, for the purpose of checking or calibrating the switchboard instruments without breaking any permanent connections or running the circuit on temporary connections. The instrument or standerd resistance \&c. is connected between two of the omnibus bars, and the dynamo or feeder \&c. is plugged on one of the lower omnibus bars; the current passes through the resistance \&c. to the top bar, which is on the outside circuit. In the actual running of the station considerable use is made of these spare omnibus bars.

Battery.-... In ordinary circumstances the two outer ends of the batteries are plugged on to the top omnibus bar on the positive and negative sides of the switchboard; but can be disconnected either by removing the plugs or by the emergency switches. One of the cells near the inner end of each battery is connected with the middle wire through the regulating switch. Save under exceptional circumstances however, the electromotive force of the whole battery in series would be much too high for the circuit; and therefore by means of a regulating switch any number up to twenty-six of the inner cells of each battery can be put in parallel with the inner cells of the other battery, thus keeping the electromotive force of the battery the same as that required at the omnibus bars to which the feeders are connected. When the dynamos are running, the battery-regulating 
switch can be set so that no current is passing into or out of the battery : putting more cells in parallel will lower the electromotive force of the battery, which will then be charged by the dynamos; while putting fewer in parallel will raise the electromotive force of the battery, and cause it to discharge and thus to help the dynamos. Under normal circumstances the battery is charged while the load is light, more or less current being put into the battery as the load on the external circuit varies, so as to keep the engines running at that time as fully loaded as possible. During heary load the battery is kept as far as possible with no current going either into or out of it; only after the dynamos are stopped is it discharged at all heavily, or when the load suddenly rises, and then only for short intervals. This method of regulating the battery by putting the centre cells in parallel, which is due to Mr. B. M. Jenkin, necessitates connecting up to the regulating switches more cells than the usual arrangement of regulating by cutting out cells on the outer ends of the batteries; but it renders the manipulation of the battery much more simple, and does away to a great extent with the somewhat troublesome charging of the back cells, that is to say the cells at the outer end of the batteries, which also in the usual arrangement may be used for only a few hours or even only a few minutes in the day, while they have always to be charged and kept ready for work.

Battery Connections.-The connections to the battery are shown on the diagram, Plate 148, whereon is roughly indicated the actual manner in which the switches \&c. are arranged. The connections may appear somewhat complicated; but in actual work the regulation of the battery is effected by moving only one wheel, like a steering wheel, fixed on the middle slate of the switchboard. The switches themselves are placed in the battery room above, and are worked by wire ropes from the wheel below. A special circuit and switch is provided, by which the cells that are in parallel can be charged independently of the rest of the battery; but in actual work this is not regularly used. In this arrangement of battery regulation the whole of the cells in the battery are always used, but the centre 
eells are not charged or discharged to such an extent as those which constantly remain in series. By properly choosing the time of charging, the regulating cells can receive rather more charge than they discharge; and in order to enable the charging to go on at light load, when there is only a small drop on the feeders, the "hospital" or "milking" cells are connected up, as shown in the diagram, four on each side of the system, through two small switchboards on the switch platform. By suitably arranging the switches these cells can either be put in series with the main battery, or be put between the dynamo charging the battery and the feeders; in the latter case part of the current goes to the battery and part on to the circuit. The electromotive force of the dynamo charging the battery can thus be made higher than that required at the station end of the feeders; and the battery can be charged with more of the regulating cells in series than would be possible if it was in parallel with the circuit. This arrangement has the additional advantage that full use can be made of the hospital cells, which are usually standing idle unless any cell in the battery requires assisting. When used for this last purpose, the hospital cells are cut entirely off the circuit, and are put, two in series, in parallel with any cell which shows signs of weakness during the discharge of the main battery; connections are made from the hospital-cell switchboards in the engine room to terminals in the battery room, and adjustable resistances and ampèro meters are put into each of these circuits, so that the current passing from the hospital cells to the weak cell can be regulated, and is always under control of the switchboard attendant.

Battery Room.-The battery room is directly over the west end of the low-tension engine-room, Plates 143 and 147, and is reached by a spiral staircase directly from the switch platform, Plates 146-7. It has a fire-proof floor covered with acid-resisting asphalt, and is well lighted and ventilated, having windows on both sides of the room, as well as a ventilator in the ceiling. The battery consists of 132 cells of the new Crompton-Howell 31-plate type. It is divided up into two half batteries, positive and negative; and is arranged in two tiers 
on four rows of stands, which are of cast-iron with wooden longitudinal bearers carrying the cells; the eight hospital-cells are arranged on separate stands. All the cells are similar, and have each a nominal capacity of 1,000 ampère-hours, the normal rate of discharge being 200 ampères. They are contained in lead boxes, and stand on glass oil-insulators upon the longitudinal wooden bearers. The 26 cells in each half nearest the middle wire are connected up by solid copper rods with the regulating switchboard, which stands directly over the main switchboard below. Provision is made for a second battery of similar size, should it be necessary in the future. In the battery circuit there is a registering ampère-hour meter between the outer end of the battery and the switchboard, so connected that its pointer goes backwards on the dial during the charging of the battery and forwards during the discharge. The mechanism is such that the pointer is 10 per cent. slow on the charge; thus if the pointer is always brought back to zero by charging the battery, 10 per cent. more current will be put into the battery than is taken out. This percentage can be altered from time to time as may be judged necessary. The regulating switchboard is connected up to the battery bars on the main switchboard, which are similar to the dynamo bars, and is also connected up to the middle wire. These connections, as well as the special connections for charging the parallel cells and for the hospital-cells, are carried in the form of bare copper rods by insulators on the engine-room wall to their respective terminals. The battery has ample capacity to meet the whole of the Ioad of the station from daylight till the evening; thus during the summer time it can do the lighting during more than half the whole twenty-four hours.

High-tension Engine-Room.--The high-tension portion of the station consists at present of only two engines and alternators $A$ with their switchboard, Plates 144 and 145, and the rectifiers $R$ for arclighting with their regulating arrangements and switchborrd; but in the immediate future this plant will be considerably extended. Each of the alternators $A$ is driven direct by a Willans three-crank engine 
of 150 I.H.P. on the same bedplate. The alternators are of the "Portsmouth" type, with some modifications necessary owing to their increased speed of 450 revolutions per minute. Their armatures are stationary, and are of great strength; the core, consisting of sheet-iron segments, is solidly bolted into the framing of the machine, with the coils threaded through holes in the sheet iron, well insulated, and completely enclosed in brass boxes. The field magnets revolve, and consist of two heavy cast-steel dises, having on their circumference claws projecting sideways alternately over the field winding, which is between the dises and is well protected from injury. The exciting current is taken from the low-tension switchboard at 230 volts, and is only a few ampères. The alternators work at an electromotive force of between 2,000 and 2,200 volts with a frequency at present of $52 \frac{1}{2}$ complete alternations per second. The main leads from the alternators, which are concentric, as well as the leads for the exciting current, are taken to the switchboard in chases similar to those in the low-tension engine-room. The arrangement of steam, exhaust, and drain pipes is similar to that already described for the low-tension engine-room.

Switchboard. - The switchboard stands on the switch gallery, Plates 144 and 145, and is built up of slabs of slate, forming shelves projecting from the west wall of the engine-room, and divided up into compartments for each alternator and circuit by slate partitions. The outer pole of each circuit and each alternator is connected to an earth plate at the station, the whole of the rest of the system being insulated from earth; owing to this arrangement all the switching can be done on the inner pole, which renders the switchboard and its manipulation very simple. The inner pole of each alternator and each circuit is connected to two similar switches through ampère meters and fuses, and can by these switches be connected to either or both of two omnibus bars at the top of the switchboard. In this way any alternator and any circuit can be connected, and the system can be worked at two different electromotive forces if necessary. The primary object of this arrangement however is to enable a machine to be thrown into circuit rapidly, by running the machine up to 
full volts on ono omnibus bar, and changing circuits over from the other omnibus bar, on which the other machine is running, without having to synchronise the second machine; the two omnibus bars can then be synchronised, the alternator and circuits changed over at leisure, and all the circuits and alternators run in parallel. In the outer circuit of each alternator is connected a registering watt-hour meter for measuring its output. Volt meters are connected between both of the inner omnibus bars and the outer omnibus bar; and duplicate synchronising transformers with lamps and switches are provided between the two inner omnibus bars. In the exciting circnits are ampère meters and regulating resistances, the switches of which are placed opposite the switches and ampère meters of their respective machines. At present the switchboard is arranged for only two alternators and two circuits; but it can be readily extended when required, the gear for new circuits extending in one direction, and that for new alternators in the other. The two circuits are at present connected only to the rectifiers for arc-lighting.

Rectifiers.-Opposite to the alternators, and standing on the same foundation block, are placed the Ferranti rectifiers $R$ for the series arc-lighting, Plates 144 and 145 . These are three in number, one for each of the two circuits, and one to spare. They each consist of a self-regulating transformer, of which the primary winding is connected to the omnibus bars of the high-tension switchboard, and the secondary winding is connected through a commutator and distributing switchboard to the arc-lamps. One winding is hung on knife-edges in a frame, and is capable of movement nearer to and further from the other; this automatically keeps the current in the secondary winding constant at 12 ampères, varying the electromotive force to suit the number of lamps in circuit. The current from the secondary winding of the transformer is then changed, by a commutator driven by a synchronous motor, from an alternating current to a uni-directional pulsating current, which is distributed to the lamps. A small distributing switchboard is placed at $I$, Plates $144-5$, close to the rectifiers, by means of which any rectifier can be put on to either of the high-tension omnibus bars, and either 
circuit of arc-lamps can be put on to any rectifier; and provision is made on this switchboard for extending the number of arc-lamp circuits.

Schedule of Machinery and Plant in the Station.-In the boiler house, Plates 141 to 143 , are six boilers of $10 \mathrm{ft} .3$ ins. mean diameter and 12 feet length, each estimated to evaporate actually 10,000 lbs. of water per hour; all fitted with superheaters and mechanical stokers; contractor, Mr. G. Sinclair, Leith. One duplex steam feedpump. Two electrically driven feed-pumps.

In the engine room, Plates 143 to 147, the low-tension plant comprises eight Siemens dynamos: two have each an output of 450 ampères at 135 volts; two of 220 at 275 ; two of 600 at 260 ; and two of 865 ampères at 260 volts. The contractors for the engines, dynamos, steam and exhaust piping, feed-pumps, heater's \&c., were Messrs. Siemens Brothers and Co., who also supplied the switchboard and all connections.

The high-tension plant in the engine room consists of two alternators, Plates 144 and 145, each having an output of 40 ampères at 2,100 volts; a high-tension switchboard; and three rectifiers for arc-lighting, with switchboard. The contractors for the whole were Messrs. S. Z. de Ferranti.

In the battery room, Plates 143 and 147, are 140 Crompton-Howell 31-plate cells, for which the contractors were the Crompton-Howell Electrical Power Storage Co.

Mains.-In the three-wire system of distribution for the northern and central districts, the electromotive force between the two outer conductors, positive and negative, is 230 volts, while that between the middle wire and the positive or negative is 115 volts. The latter is the electromotive force of the lamps on the consumers' premises, no trouble being now experienced in obtaining glow-lamps to work at this electromotive force, or even higher. Distributing mains are laid throughout the streets marked by fine full lines in the map, Plate 140; all three wires are laid in those streets where the demand for current is large. In the other streets the positive and middlo wires are laid 
on one side of the street, the negative and middle on the other; and a spare way is left on each side for a third conductor, should the demand require it. The distributing mains are all in parallel, and are connected up throughout the system; rings are completed wherever possible, so as to ensure equality of pressure, and to admit of disconnections being made without interrupting the supply.

Feeders.-The feeders from the station, which are marked by fine dotted lines in the map, Plate 140, are connected to the distributing mains at sixteen points. They consist of two conductors only, the positive and negative; the middle wire is inter-connected throughout as much as possible, and is brought back from three districts on the system. The eables are put in parallel at the station, and one connection only is made to the switchboard. The positive and negative sides respectively of all the feeders are put in parallel at the switchboard; but any feeder or feeders can be put on a separate machine if required.

Balancing.-As far as possible, consumers in each street and district are balanced against one another by connecting them alternately between positive and middle wires and between negative and middle wires; large consumers have all three wires taken into their premises, and their lights balanced against one another in a similar manner. But however carefully this balancing is done, it is impossible to get a really accurate balance; the "out of balance" current varies from hour to hour and even from minute to minute, and is different on different days of the week. The amount out of balance is compensated for at the station by means of the balancing machines, either of which can be put on either side of the system; the balancing during the light load is done from the battery alone. Light wires, forming potential leads or pilot wires, are brought back from all three conductors at each feeding point, and are connected to the feeder volt meters on the switchboard: so that the pressure at the feeding points at any part of the system is directly known at the station, and the necessary regulation made for keeping the 
electromotive force constant. The distributing mains are brought back to the station, but are used only for the supply of light and power there; no regulation is done on the mains anywhere, except to the feeding points.

High Tension.-No high-tension feeders or distributing mains have yet been laid. They will be laid as concentric cables in ring circuits, and banked transformers in small sub-stations will be used wherever advisable, while houses in districts where the lighting is scattered will be served by isolated transformers. The concentric cables will be pulled into Doulton stone-ware casings under the footways, and into east-iron pipes under the roadways. The casings have already been laid in those streets which have been opened up for the low-tension mains; and the work of laying the high-tension mains in the southern and eastern districts is now being proceeded with.

\section{ROADWORK.}

Distributing Mains.-Practically the whole of the distributing mains are laid as cable insulated with india-rubber, heavily braided, drawn into Doulton stone-ware casing under the footways, and into either Crompton-Davis cast-iron casing or cast-iron pipes under the roadways, Plate 149 . At all crossings, and at intermediato places on the footways, brick junction-boxes are built for the purpose of drawing in, connecting, and testing. Smaller brick service-boxes are provided at suitable intervals, where connections are made to consumers; but for this purpose, when space is limited, a special length of Doulton casing is provided, which is so made that it can be easily split longitudinally and removed; the house connection is then made with vulcanised joints, and the casing replaced and jointed up with a special collax and bitumen cement. The collar is provided with a socket, into which the pipe carrying the house connection can be jointed. A mark is made on the kerb to indicate the position of the service-bo: ; and the pavement is then replaced. These service-boxes are found to be of great use, owing to the number of cellars under the parement. The brick junction-boxes are covered with a cast-iron 
frame, which is fitted with a cast-iron cover filled in with concrete, a water-tight joint being made with the frame. In most places the bottom of the box is filled in with dry rubble, so as to form a drain for any water which may find its way in; but where water has been found in the soil, the bottom of the box is concreted, and the whole made water-tight. Where it has been necessary in some places to put junction-boxes in the road, they have been made as water-tight. as possible, and covered with a double cover, the upper being a heavy cast-iron cover with wood blocks let into it. Boxes in the road have been aroided as much as possible, as it is found so difficult to make a satisfactory job of them. In a few places the distributing mains have been laid as bare copper strip, carried on stone-ware insulators in concrete culverts.

Feeders.-Wherever sufficient space has been found under the footways, the feeders have been laid as bare copper strip, carried on stone-ware insulators in concrete!culverts. Across all roads, and where there has not been sufficient space for culvert, the feeders are laid in Siemens armoured cable, laid direct in the ground with a tarred board over them to act as a protection to them and as a warning to any workmen opening the ground. The cable has everywhere been laid of greater section than the copper strip in the rest of the feeder, so that the capacity of the feeder can be largely increased, and yet the resistance be kept right, by pulling in additional copper strip into the culverts, without bringing the current density up to any excessive amount in the portions laid in cable. Thus the feeders can be made to carry considerably more current than that for which they are now designed, with the same drop of electromotive force, and without either disturbing the streets or over-running any of the cables. All the feeders have been designed to have a total drop of 44 volts at full load. In the culvert the copper strip is laid in lengths of about 20 yards, with a brick inspection-box at each joint; so that the culvert can be easily seen by means of a lamp pushed into it, and the strip can be readily drawn out and in, as required. The joints are made by tinning the onds of all the strips, and clamping them together by a gun-metal grip-box with 
two $\frac{5}{8}$-inch bolts; at the feeding points the feeders are conuected to the mains by short pieces of cable. Everywhere the culvert is kept quite straight in plan, but with a fall towards every junction-box or inspection-box. The strip is in no place lower than 2 feet below the level of the pavement; for it has been found elsewhere that it is impossible properly to inspect or do any work to culverts which are constructed at any great depth. There is nowhere any culvert under a roadway.

Potential Leads.-These lines, by which each feeding point is connected back to the station, consist each of three sets of wires, insulated with specially prepared paper, laid up together, and covered with the same material, a lead tube being drawn over the whole. These leads are drawn into special ways, either in Doulton stone-ware casing or cast-iron pipe, laid alongside the culverts ; and are joined up into one length back to the station. The joints are made in a brass tube, soldered on to the lead sheathing, and containing insulating oil ; the wires are kept separate from one another by fibre discs.

Connections. - The whole of the cable connections are made by cone connectors, sweated on to the cables, and fitting into gun-metal connecting-blocks, Fig. 11, Plate 149. The cones are all the same size for all sizes of cable, and are interchangeable; when the section of cable exceeds 0.7 square inch, two cones are used; the taper employed is one in eleven, which makes a good fit and is yet readily disconnected. The cone connecting-blocks are made in four sizes, having severally two, three, four, or five holes bored in them. The holes are bored conical to fit the cones on the cable connectors; and the blocks are interchangeable with one another. The armoured cables, which are all of large section, have special connectors sweated on to them, and these have either one or two of the standard conical holes bored in them; the connections to the distributing mains are then made by one or more short lengths of cable having cone connectors at each end. Enough slack is left in the boxes to allow the ends of the cables to be turned upwards; they are then connected together by slipping the connecting-block on them, and 
the cones are drawn tight into the holes by means of a nut fitting upon a $\frac{5}{8}$-inch screw on their ends. In order to obviate any trouble from end leakage through water dripping on the bare terminals, and also to minimise the risk of short circuits through accidental contact between the blocks, stone-ware caps are dropped over the connectors, and entirely cover all bare metal.

Public Lighting.--The streets bordered by thick dotted and thick full lines in the map, Plate 140, are lit by electricity, by means of altogether 176 public arc-lamps. In the streets bordered by thick dotted lines the arc-lamps are run four in series off the distributing mains shown by fine full lines; and each series of four is provided with a fuse, switch, and line resistance. Each lamp in the series is also provided with an automatic device, which, in the event of the lamp failing, cuts it out and introduces into the circuit a resistance equal to the lamp, so that the other lamps in that circuit are not affected. The lamps in Princes Street are constructed for a normal current of 15 ampères, and all the other low-tension lamps for 10 ampères.

In the streets bordered by thick full lines, in which no lowtension mains are laid, the lamps are run on special high-tension series-circuits from the rectifiers at the station. There are at present two series-circuits, both of which are laid in all the streets lit by high-tension lamps, and the lamps are connected alternately to each circuit. The circuits are laid as concentric cable drawn into cast-iron pipes, the outer conductor of the cable being insulated. There are twenty-four lamps on each circuit, each provided with an automatic cut-out in caso of its failing to act; and also with a switch in the pillar, by which it can be entirely disconnected from the circuit if necessary, while the switch is so made as to complete the circuit for the other lamps.

In arranging the circuits for the arc-lamps, care has been taken to put alternate lamps on separate circuits in all streets, whether run from the distributing mains or from the series circuits. This minimises the risk of any street being left in darkness by the failure of any circuit; and also allows half the lamps to be switched off at or 
about midnight, still leaving the streets well lighted. The arc-lamps are of Crompton-Pochin type, and are fitted with 18-inch spherical globes. They hang from the bracket of a cast-iron pillar, the centre of the globes being 23 feet above the level of the parement. In Princes Street the lamps are about 45 yards apart, and are on one side only of the street. In the other parts of the city the lamps are about 60 yards apart, and are placed alternately on the two sides of the street.

No contractor was employed for the roadwork or laying of the mains; the whole of this work, including the erection of the arclamp posts, was carried out by the Resident Engineer, Mr. E. W. Monkhouse, with his own staff of workmen. The armoured cables were supplied by Messrs. Siemens Brothers and Co.; the unarmoured cables by the Henley's Telegraph Works Co., and the India-Rubber Gutta-Percha and Telegraph Works Co., Silvertown. The potential leads were supplied by the British Insulated Wire Co. The stoneware casing was manufactured by Messrs. Doulton and Co., and the cast-iron work by Messrs. Maclaren and Messrs. Shaw and Co. of Glasgow. The copper strip was supplied by Messrs. Bolton and Co. of Oakamoor Works. The posts for the arc-lamps were designed by the Edinburgh School of Art, and the castings were made by Messrs. Mackenzie Brothers of Edinburgh. The whole of the arc-lamps were supplied and fixed by Messis. Crompton and Co. of Chelmsford, who also supplied the cable-cones and connectors.

In this account of the electric lighting of Edinburgh the author has endeavoured to describe the arrangement of the plant and mains, and any details in their design and construction which may be of interest, without discussing general principles or the advantages or disadvantages of any individual system. Having himself had the good fortune to be connected with this particular work from its earliest stage to its opening, he desires to express his deep indebtedness to Professor Kennedy for permission to prepare the present paper and to use the drawings from which the illustrations have been prepared ; and also for his suggestions and assistance, without which it would have been impossible for this paper to be laid before the Institution. 


\section{Discussion.}

Mr. Bunstall drew attention to specimens brought from Edinburgh by Mr. Monkhouse, the Electrical Engineer to the Edinburgh Corporation, of cone connecting-blocks, cable joints, and stone-ware caps; and also to photographs of the low-tension engineroom and switchboard, and of the alternators and rectifiers. A collection of Doulton casings was lent by Messrs. Doulton and Co., containing two, three, and four ways; also connection boxes with three and four ways; jointing mandril for casings, and joint mould for two-way casing; and two-way and three-way insulators.

Mr. William H. Patchell, Chief Engineer of the Charing Cross and Strand Electricity Supply Corporation, asked why alternators were put in for the outlying districts (page 553). It appeared to him that the work might have been done just as well, and probably better as far as the load factor of the station was concerned, by putting in continuous-current transformers to be worked at hours of low load, and high-tension direct-current machines for the feeders at the high loads, when it was worth while running separate machines. In that way it seemed to him there would have been a chance of getting a really good load-factor.

The question of electrical pumps (page 555) was also one in which engineers were all much interested at the present time, in view of the notorious inefficiency of the ordinary duplex pumps, than which he thought nothing could well be better as steam eaters, while certainly as pumps they might be much worse. They were always ready when called upon, and from this point of view should be given credit for having done yeoman's service. But when it came, in these days of close competition, to sitting up all night in order to save a fraction of a penny per unit, it had to be considered whether electrical pumps were not cheaper. From whichever side the question was regarded, whether from the steam side or the electrical side, he thought it could be proved with equal satisfaction that either pumping was as cheap as the other. He asked how the load was divided 
on the pumps so as to get a good load-factor on the motors. There was an arrangement he noticed for connecting the pumps with either the 115-volt or the 230-volt mains; but even then, how did the actual working of the pumps come out in efficiency? At this early stage it might be too much to ask whether the electrical pumps were really cheaper than steam pumps in their working, but it would be interesting to learn this, if it had yet been ascertained.

The matter of superheating (page 554) was one he had been much interested in for the last two years, having adopted the system for more than that period; and he was glad to find that other stations were going in for it. Were there any figures to be had with regard to the testing of the superheater as it now stood? The shape of the pipes in the present arrangement seemed to him not altogether satisfactory, for he thought there must be a good deal of wet in them, and he did not quite see how that wet was going to pass through, or whether the superheater would not be acting rather as only a sort of water-trap. With ordinary stoking the temperature of the flue gases would be $750^{\circ}$ or $800^{\circ} \mathrm{Fahr}$. at the outside; and he enquired how many pipes went to make up the superheater for each boiler, whether thirteen or twenty-six.

The President replied that there were twenty-six superheating pipes to each boiler, thirteen on each side.

Mr. Patchell had had no experience of superheating at the engine stop-valve. All he had used superheating for was to overcome the condensation in the steam pipes. Eventually he hoped to carry out superheating at the engines, but he had not got so far yet. The superheaters he was using were applied only to two boilers out of seven, the other five not being fitted with any superheating apparatus; and in the ring of steam pipes he could get by this means about $10^{\circ}$ superheat in the steam; but this practically counted for nothing at the engines.

Mr. Bryan Donkin, Member of Council, asked whether superheating had been tried at the Edinburgh station for any length 
(Mr. Bryan Donkin.)

of time, and what was the average temperature in the smoke flue outside the superheating tubes, and also the degree of supcrheat over and above the temperature of the saturated steam.

Mr. William Garpel, Superintendent Engineer to the Brugh Electric Engineering Co., said that in so complete and detailed a description of the Edinburgh Central Station he should have been glad if some information had been given both as to the cost of the undertaking, and as to the tests and efficiencies of the various portions of the machinery. Like the last speaker he was curious to know what was the amount of superheating obtained from the flue gases after they had passed through the boiler tubes. There was no doubt that it was an excellent thing to superheat the steam, in order to compensate for the heat lost between boiler and engine; but it seemed to him that, when the superheater tubes became coated with soot, the passage of heat through them would be comparatively small, owing to the low temperature of the flue at that point. It was true that, whilst the boilers were being forced, the flue temperature wonld be somewhat higher beyond the boiler tubes; but better results in superheating could be obtained if the heater were situated in a flue where high temperature was always available. It was also to be remembered that there was more necessity for superheating at light loads, because the velocity of the steam in the pipes was then lower, and consequently the loss by radiation per pound weight of steam was greater, while conversely there was less heat available in the flue for superheating. A certain amount of superheating could be obtained, as was well known, by working boilers at a higher pressure than the engines were worked at, and throttling the steam at the stop valves of the boilers or engines. In that way some objections in the working of superheaters were got rid of, such as the deterioration of the superheaters themselves, which he believed was somewhat rapid. Certainly a higher boiler-pressure did not give a high degree of superheating; but it might give a sufficient amount to supply at any rate dry saturated steam to the engines.

The drain-valves he noticed (page 555) were all connected to a common steam-trap, thereby necessitating the use of a non-return 
valve at each drain, and increasing not only the number of valves requiring. attention at starting, but also the number of highpressure joints and the extent of radiating surface; the last especially was a matter of serious consideration in an electric lighting station. His experience was that it was better in every way to apply a separate steam-trap at each point. The trap should be of the open kind, that is, the valve should be always open, except when dry steam attempted to pass. If in turning on steam it were known that each drain was naturally open, and that each would close whenever there was only dry steam to pass, the attendant's duties would obviously be lightened. More especially was this an advantage in case of a sudden emergency, when all possible time should be saved.

The plan of using electric motors for driving the mechanical stokers and feed-pumps was one which he could recommend from experience. Small steam cylinders driving feed-pumps were proverbially wasteful; and as to slow-running direct-reting steam feed-pumps, they were simply steam eaters, and should on no account be used, except as stand-by pumps. Where steam was used at all for continuous boiler feeding, it should undoubtedly be through the medium of a quick-running engine with early cut-off, geared indirectly to the pump.

It would be interesting to know why one of the several sources of water in Edinburgh had not been utilised for condensing. In central stations he had found condensing most economically applied, more especially to the engines which were most in use.

In regard to the use of steel flanges on the copper bends in the steam pipes (page 557), he asked whether the flanges were of cast malleable steel. If they were, he understood there was a tendency for electrolytic action to take place, which in the course of years affected the joint; and he should be glad to know whether this had been found not to be the case, even after many years of use.

In the steam pipes he should expect vibration to take place, if they were merely slung by long rods (page 557) without being stayed at one or more points. 
(Mr. William Geipel.)

The plan adopted of covering the flanges of the steam pipes (page 557) appeared highly desirable, when it was remembered that each square foot of bare steam-pipe surface lost half a ton of coal per annum, if in constant use. Details of the method adopted of covering the flanges would be interesting.

It might be much doubted whether the use of a large number of small units of machinery, entailing so complex an arrangement of switchboard, was what would be generally recommended for a central station. The work of attention must be greatly increased thereby, as well as the cost of duplicating so many parts. When it was remembered that the low-tension supply and also the lighting of arc lamps, together with scattered suburban lighting, could all be carried out from one set of machinery on the alternating method, he could not sec wherein lay the advantage of a combination of alternating and continuous-current dynamos together with motor rectifiers. If it could be shown that there was considerable saving in first cost, there would be somo ground for such a plan; but as the first cost, instead of being less, was in reality greater, owing to the greatly increased quantity of copper required on the lowtension direct plan, he could not help thinking that a large city like Edinburgh should have commenced with fewer and larger units of machinery and on the alternating plan.

In the high-tension portion of the station it seemed to him unfortunate that the odd number of $52 \frac{1}{2}$ complete alternations per second had been adopted (page 565). The multiplicity of periodicities would seriously prevent manufacturers of electrical machinery from keeping in stock a supply of transformers and motors. It was most desirable that some arrangement should be come to, whereby the variety of periodicities adopted might be minimised. To bring this about would be useful work for the electrical section of the London Chamber of Commerce.

The difficulty of keeping the pressure constant, owing to the variation of the balancing from hour to hour, had been rightly referred to in page 568. It would be interesting to know whether in the course of a few years that diffeulty would not be greatly increased in such a system of feeders as was used for Edinburgh. 
It seemed to him doubtful whether the omnibus bars would then be of much service, except for light loads: unless indeed wasteful rheostats or similar resistances were inserted in each feeder, and the station voltage were increased above the average requirements.

In the junction-boxes of the distributing mains, Fig. 11, Plate 149, it seemed to him that the bending of so large a cable to so small a radius as was there shown must be apt to injure the insulation. Moreover the moisture condensing on the porcelain eap would keep dripping upon the portions of the insulation underneath; and it appeared to him that in course of time this drip would affect the insulation of the cables. Doubtless such a result would take some years to come about; but eventually he thought this would be found to be a weak point in the plan, as the rubber would not stand continual alternations of drying and wetting.

Mr. E. Tremi.etr CarTer pointed out that the superheating or drying action adrocated by Mr. Geipel (page 576) took place to some extent in engines governed by throttling, at low loads especially; and if, instead of generating the steam in the boiler at a higher pressure than the initial at full load, it were generated at the actual pressure required for full load, there would at light loads be a certain amount of drying action in an engine governed by throttling and not by variable cut-off. Moreover the drying action would be greater as the velocity of the steam in the pipes was lower, that is, when the load was lower, and when consequently the liability to condensation in the main range of steam pipe would be increased. In this way there was a little compensation, but he thought not much; at any rate not enough to compensate altogether for the condensation in the steam pipe. To generate steam at a much greater pressure than was absolutely required at full load, and then to throttle it down, in order to balance the condensation which would take place in the range of steam pipes, he should think would be a much more expensive way of getting rid of condensation than to use a superheater, especially if the superheater were placed sufficiently forward in the boiler flues to obtain the benefit of the heat first-hand instead of second-hand. 
Mr. William H. Patohell mentioned, with reference to electrolytic action between the copper and steel in the steam pipes (page 577), that some time ago, when using copper jointing pieces for steel pipes with steel flanges, he had found they stood well with ordinary London hard water, and there was no trouble at all with them. But when water was used which boiled alkaline, such as the deep chalk water in London, they had given trouble after trouble, and he had had to take out the whole lot of the copper jointing pieces. Every one had become corroded at the bottom side of the pipe. This he attributed almost entirely to the alkali carried over by the steam from the boiler, which did not give particularly dry steam, and to the subsequent condensation in the pipe. The bulk of the damage was where it would be expected, namely in the bottom of the pipe; and that was where every one of the joint rings had failed. In using compound pipes therefore, of copper and steel, it was necessary to consider what class of water was being used, and how it was being evaporated.

Mr. SxDniy W. Baynes, Electrical Engineer to the St. Pancras Vestry, thought there was not really much cause for alarm in regard to the bending of the cables in the junction-boxes (page 579); the radius did not look to him so small as to bring about any injury to the cables.

With regard to the question raised as to the necessity for employing rheostats on the feeders (page 579) as soon as they became loaded up, this theory would be found contrary to actual experience. In practice feeders supplying a network, if well proportioned, seldom varied relatively more than 2 per cent. in pressure. In the event of excessive variation, it would be simpler to amass those of known voltage on to a separate omnibus bar, fed by a dynamo at suitable pressure: so that the expensive rheostats suggested would not be found necessary. At Bradford the station had been started with expensive rheostats; and later on, as the mains were loaded to even 50 per cent. in excess, the rheostats were not required, as the load was found to have become fairly even. There was not a variation of more than $1_{\frac{1}{2}}^{\frac{1}{2}}$ per cent. between any of the mains 
throughout the town. He was himself inclined to adopt a higher voltage throughout, which would greatly modify any difference that there might be between the feeders, because a variation of 2 per cent. on the feeders when running at a high voltage would give a larger working range for actual fluctuation than at a lower pressure.

He asked what was the weight of water evaporated from and at $212^{\circ}$ Fahr. per pound of coal consumed; and also what was the rate of the evaporation at the time of making the tests; and the class and price of the coal.

Mr. E. R. Douby asked whether any difficulty had been experienced from vibration in the suspended ring of steam pipes. Recently in a central station he had seen a ring main held up by being slung in the manner described in page 557, which he considered was by far the best way of hanging steam-pipes so as to allow for expansion; but in the particular station he had visited the suspended ring-main was in a vertical plane. The main was about 70 or 80 feet long, the circuit rectangular in shape, and the top and bottom pipes were about 6 feet apart. The top line of pipe was hung up by links to brackets, exactly as described, and the bottom line of pipe was hung up to the top pipe, so that the whole ring was hanging on slings from brackets. The pendulum motion in the ring main he was told was so excessive that brackets with rollers had had to be put under the lower part of the ring main. When the brackets with rollers were put under, the expansion did not take place so freely as before; and therefore the middle of the pipe had to be held fast from moving, and an expansion joint put in at each side. It was quite possible that where the ring main was in a horizontal plane there might be no such vibration, and he should be glad to know what experience there was on this point; but if the ring main was in a vertical plane he thought that might not be the best way of supporting it.

Mr. E. W. Monkнолs: showed a diagram, Fig. 13, Plate 150, of the total units generated in the Edinburgh station, the total number of lamps lit, the maximum load, and the total cost per unit, for every 
(Mr. E. W. Monkhouse.)

week from the beginning of the second week in which the work was started to the week ending 10 th October. It would be seen that the work started with about 2,500 lamps, and had gone up to 34,000 lamps. The cost per unit to begin with was fairly uniform per week. It went up a little as the load went down in June. From 27th June until 4th July it went down suddenly. It then went up again a little, because of the increase in the staff; and since then it had continued to go down, and had now got down to 0.9 penny per unit generated. The lowest cost per unit generated, in any one week, had been 0.886 penny. The highest cost per unit generated had been in the eighth week, June 6-13, and was 1.78 penny. At that time naturally the machinery had not been running quite as smoothly as it did now, and there had been various little things to be done, and rather more money had had to be spent. The cost per unit generated at the terminals, for the week ending 10th October was as follows:$0 \cdot 127 d$., wages $0 \cdot 313 d$., fuel $0 \cdot 319 d$., stores $0 \cdot 026 d$., water $0 \cdot 034 d$., and repairs and carbons for the 177 are lamps $0.088 d$.; making altogether $0.907 d$. per unit generated. The efficiency of the station, that is, the ratio of the units sold to the units generated, was 88.4 per cent. The cost to consumers, or the cost of the units sold, was $1 \cdot 09 d$, which he thought was fairly low for a station only six months old.*

There were now in Edinburgh altogether $24 \frac{1}{2}$ miles of lowtension road work, of which about 22 miles were distributing mains and the remaining $2 \frac{1}{2}$ miles wore feeders. There would be altogether about 8 miles of high-tension road work when the ring main was completed which was now being brought out to the Meadows on the south side of the city.

* Since 10th October the cost per unit generated has fallen considerably, and for the week ending 28th November was as follows:-station salaries $0.078 d$., wages $0.195 d$., fuel $0.261 d$., stores $0.019 d$., water $0.020 d$., and repairs and carbons for 184 arc lamps $0.054 d$; making altogether $0.627 d$. per unit generated. The efficiency of the station, that is, the ratio of the units on circuit to the units generated, was 88.4 per cent. The cost to consumers or per unit sold was $0 \cdot 764 d$. 
With the suspended ring-main of steam pipes at the station he had observed no vibration, and had had no trouble from that cause with any of the joints; the only trouble with joints had been from other causes.

Mr. JoHs G. MaIr-RumLeq, Member of Council, asked whether any trials had been made with the superheaters and without them, and whether any idea could yet be given as to the saving which had been effected by their use. The adoption of superheating was an exceedingly interesting question. Its advantage undoubtedly depended a great deal upon keeping the superheaters clean. One superheater which he had at work on the Schwoerer plan he had had a great deal of trouble in keeping clean, and practically no superheat could be got out of it; but after putting steam-pipes round about it and cleaning the spaces by means of steam-jets, the temperature of superheat had been brought up to $100^{\circ}$ or $120^{\circ}$ Fahr. at the superheater. It would be of interest if the author could give the temperature of the superheat that was obtained at the superheater, and also the temperature of the superheat at the engine stop-valve, in order that the loss between the two might be known.

With reference to steam-pumps, there was no doubt that a steampump badly used was highly wasteful. But having tested a small direct-acting pump both with and without superheating, he had found that exactly half the steam was saved by superheating. The worse the engine, the larger of course was the amount of saving obtained by using the superheater. If the exhaust steam from the steam-pumps was taken to heat the feed-water (page 555), the loss from the wasteful use of the steam by the pumps would not be large.

Professor T. Hudson Beare shared Mr. Mair-Rumley's desire for more information about the effect of the superheating, which had been rather discredited by Mr. Geipel (page 576) because of the probable low temperature of the gases by the time they reached the superheater; while it had also been found that sufficient superheating could not be obtained in some arrangements to be 
(Professor T. Hudson Beare.)

perceptible at the engine stop-valve. From experiments which he had himself been making recently as to the effect produced on initial condensation in the cylinder by moisture already contained in the steam when it arrived at the engine, he felt sure that, if superheating were only sufficient to ensure getting dry steam into the engine, one great difficulty would be conquered. There was a marked difference between the amount of initial condensation when absolutely dry steam was admitted into the cylinder, even without any superheat and at only the natural temperature of the steam, and when steam was admitted which contained only a comparatively small amount of suspended moisture. Even if superheaters did nothing more than ensure really dry steam at the engine stop-valve, he felt sure they would have a large share in inducing economy in steam consumption. The loss in the steam-pipes, which might be termed, for want of a better expression, the loss between the boiler and the engine, was much greater than was generally believed. It had become so much the habit in recent years to measure the steam consumption by the amount of water which came out of the condenser and was drained off in the steam-jacket, that it was apt to be forgotten that a great deal more than this had to be put into the boiler. There were invisible leaks everywhere, and extensive condensation was induced in the largo and long steam-pipes in all central stations. The introduction of superheating therefore in the Edinburgh station he considered ought to be welcomed, as likely to give figures which were everywhere badly wanted as to the value of superheating in eliminating these losses.

Mr. James Platr, Member of Council, considered that with the short dry-backed boilers described in the paper the superheaters ought to prove highly efficient; and that an economiser would also be of advantage. With such short powerful boilers the temperature of the gases in the chimney he thought would be so considerable that probably an economiser would pay. There was indeed a feed-heater, into which the exhaust steam from the steam-pump was delivered; and he thought a little more heat might still be got from the flue with such short boilers. In Lancashire it was thought that there 
was nothing like a good long boiler, and that there was some heat wasted in the flues of shorter boilers; it was better therefore to recover some of this waste by an economiser.

Mr. Edward B. Eluington mentioned that he had lately been making some experiments as to the quantity of coal required to keep up the steam in boilers when no work was being done at the several hydraulic-power stations in London; and he had been much surprised to find the great discrepancy that existed in the different classes of boilers. In two Lancashire boilers for instance, he had found that, when there was no work doing and the engine was not running, 14 cwts. of coal was consumed in twelve hours, including the waste of heat in the steam-jackets and economiser. In two Fairbairn-Beeley boilers, described at the last meeting (page 356), which were working under similar conditions, the amount of coal consumed in twelve hours was only $8 \mathrm{cwts.}$, as against $14 \mathrm{cwts.}$ in the Lancashire boilers. Both the Lancashire and the Fairbairn-Beeley boilers evaporated about 4,000 pounds of water per boiler per hour. Snch a consumption of coal with the engines standing amounted to a large loss in the course of the year; and he considered the principal reason of the difference between the two kinds of boilers was simply the larger amount of surface from which heat was lost in the Lancashire boilers, though at the hydraulic station where only 8 ewts. was used in twelve hours the flanges of the jacket steampipes were covered, and the dampers were so arranged as more effectually to prevent the admission of air when closed. If the information was available, he should like to know what amount of coal was consumed in one of the Edinburgh boilers simply to keep the steam up, without using it for work at all.

As to vibration of the steam-pipes (page 577), he had used ring steam-pipes in a similar way to that shown in the drawings, and had met with no trouble at all from vibration. There were no copper bends; they were all of steel. It had been found necessary to allow for a certain amount of vertical movement in the pipes, and this had been done by supporting on springs the rods carrying the pipes. There had been some trouble when there was a rigid connection vertically. 
(Mr. Edward B, Ellington.)

$\mathrm{He}$ was glad to see superheating employed at the Edinburgh station, for he thought there must be a great deal of economy to be derived from it, even should the cost of maintenance of the superheater be considerable.

Mr. William Geipel considered the particulars given by Mr. Monkhouse (page 582) respecting the working of the station in Edinburgh were most interesting; he thought they were about the best he remembered having ever heard. The cost of working a station however was only the smaller part of the total cost of the supply to the consumer. The greater part of the cost was made up of depreciation and standing charges; and it was for this reason chiefly that he had suggested the use of a smaller number of larger units. If the first cost of this station when all the distributing mains were being fully drawn upon could be brought down to anything like the cost of an alternating station, then the figures as to working cost, given by Mr. Monkhouse, came remarkably close to some which he had himself given, in the discussion upon the paper read by Mr. Crompton to the Institution of Electrical Engineers* about a year ago, as to the ideal cost of working a central station. In that estimate he had calculated the lowest cost of working a station per unit

* Institution of Electrical Engineers, 1894, vol. 23, page 480. The two estimates of working cost compare as follows with the actual cost given by Mr. Monkhouse (page 582) :-

\begin{tabular}{|c|c|c|c|}
\hline Station salaries & $\begin{array}{l}\text { Crompton. } \\
\text { Ideal cost. } \\
\quad 0 \cdot 10 d .\end{array}$ & $\begin{array}{c}\text { Goipel. } \\
\text { Ideal cost. } \\
0.20 \mathrm{~d} .\end{array}$ & $\begin{array}{c}\text { Edinburgh. } \\
\text { Actual cost. } \\
0 \cdot 127 d \text {. }\end{array}$ \\
\hline Wages & $0 \cdot 10$ & $0 \cdot 20$ & $0 \cdot 313$ \\
\hline Fuel & $0 \cdot 27$ & $0 \cdot 15$ & $0 \cdot 319$ \\
\hline Stores & 0.02 & $0 \cdot 04$ & 0.026 \\
\hline Water & $0 \cdot 01$ & $0 \cdot 01$ & 0.034 \\
\hline Cost per unit generated & $0 \cdot 50$ & $0 \cdot 60$ & $0 \cdot 819$ \\
\hline Repairs and Carbons & .. & .. & 0.088 \\
\hline Maintenance 2 per cent. & $0 \cdot 40$ & 0.22 & \\
\hline Management & 0.42 & $0 \cdot 42$ & \\
\hline Profit 7 per cent. & $1 \cdot 68$ & $0 \cdot 76$ & \\
\hline Sale price per unit, pence & $3 \cdot 00$ & $2 \cdot 00$ & \\
\hline
\end{tabular}


generated to be $0 \cdot 6 d$. excluding carbons; while in practical work Mr. Monkhouse had got down to $0 \cdot 9 d$. including carbons. Water he noticed eame to $0.034 d$. per unit; if condensing had been used, it would probably have been only a tenth of $0.034 d$.; since it was as much as 3 per cent. of the total cost, it was deserving of consideration, when strenuous endeavour was being made to reduce the cost by every fraction of a penny.

Mr. C. FreweN J JinkIN asked how the steam-pipes were connected to the engines. The main problem in allowing for the expansion of the steam-pipe, he thought, was how to allow the pipe itself to expand, and yet to make a connection from it to the fixed engine. Having arranged steam-pipes along brackets, he had found that the connecting pipes to the fixed engines unscrewed and worked loose in their flanges, owing to the forward and backward motion of the main steam-pipe in expanding and contracting. He should like to know whether in the Edinburgh station the main steam-pipe was always kept full of steam; or whether it was allowed to get cold during the day, when the load was taken by the batteries. If the latter, it seemed to him that, when more engines were put in, it must lead to trouble; for the long range of steam-pipe would expand, as far as he could make out, about 3 inches between hot and cold.

Mr. Druitu Halpin had lately seen at Aix-la-Chapelle an arrangement on a large scale for transforming a continuous current into an alternating. There were three engines of 350 H.P. each, for generating a continuous current at a pressure of 210 volts for the electric lighting; and a highly favourable bargain for the station had lately been made with the authorities to drive the tramways, extending about 40 miles through the town. For this purpose two triple-expansion engines only were added, of $150 \mathrm{H} . P$. each, without any reserve at all. These two engines were kept running all the time at full load; and when more power was wanted, the continuous current was taken from the other engines, or from their batteries which were large, and was employed to 
(Mr. Druitt Halpin.)

drive motor transformers; and by that means the expenses of stand-by engines were saved.

He could not follow the argument (page 584) that, because the Edinburgh boilers were so short, they afforded a good opportunity for the adoption of an economiser. It was surely a question simply of the amount of heating surface presented to the products of combustion, quite apart from the length of the boilers. With regard to the experiments (page 585) on the radiation from boilersequivalent to $8 \mathrm{cwts}$. of coal in twelve hours in one instance, and $14 \mathrm{cwts.}$ in another-this was highly valuable information; but there was also another factor, which he thought ought certainly not to be overlooked. In experiments carefully made by a commission* in Frankfort in 1891 great stress had been laid, and perhaps rightly, not only on the radiation, but also on the leakage of air into the boiler flues through the brickwork. By those experiments it had been demonstrated that the final efficiency of the boiler, that is, the evaporation divided by the thermal units in the coal, ran out practically in an absolutely fair curve, according to the excess of air which leaked through beyond the quantity theoretically required for combustion. The leakage of air was determined in three ways. Firstly the theoretical amount of air was determined; then the amount of air immediately behind the bridge was determined, which showed the excess coming through the furnace; and finally it was further determined at the entrance to the chimney what an enormous leakage there had been through the brickwork. If regard were paid to the condition of the brickwork and to the extent of radiation, he thought much light would be thrown upon the subject, because the extent of radiation from the boiler itself must be exceedingly small, inasmuch as there was so little of the boiler surface that was available for radiating, namely the top and front only; in the present instance also the top surface of the boiler was covered by the superheater.

* Bericht über die Arbeiten der Prüfungs-Kommission; published by J. D. Sauerländer, Frankfort-on-Main, 1894. 
Mr. Horade Wm. Wright noticed that it appeared from the drawing, Fig. 3, Plate 142, that no provision had been made for cleaning out the feed-heater, in which of course sediment would gradually collect in consequence of the heating of the feed-water therein. Whenever it became necessary to take the casing off for cleaning out the interior, he feared a good deal of expense would have to be incurred in lifting it. If proper provision for cleaning had been made when the heater was erected, much expense he considered would have been saved, which would eventually affect the eeonomy of the station.

Mr. E. W. MonkHovse said that in summer, when the station stopped working tolerably early in the light mornings, the engines did not start until nine o'clock at night; and it took 3 cwts. of coal per boiler to keep the steam up during the day, doing nothing but banking the fires.

With regard to condensation of moisture on the Doulton-ware caps in the junction-boxes (page 579), there were several boxes in Edinburgh which were particularly wet, as he supposed had always been found to be equally the case elsewhere; but he had found that no water at all got underneath the caps; on lifting the caps he had found they were perfectly dry underneath. It would be noticed that the caps were made of such a depth that any water dripping from them could drip only upon the cable itself; but the quantity of water so dripping from the caps he had found was not great at present, and the dripping had not yet continued long enough for him to find out that the rubber would not stand continual alternations of drying and wetting; and he hoped he should not find this to be the case after longer experience.

Mr. Srdnex W. Barwes suggested that all risk of injury to the insulating covering of the cables might perhaps be obviated by giving the edge of the caps a slope, so that the moisture conld drain off them at one point, and drip clear of the cables. 
Mr. Burstalc replied that the reason why continuous-current transformers were not used (page 574) was largely because of the nature of the district to be served, in which it was possible that for many years to come the lighting would be sparsely scattered; and therefore isolated transformers would have to be used. With continuous-current transformers, low-tension mains would be required.

Respecting the cost of driving the electrical pumps (page 575), no information he believed was at present forthcoming. Although it was known how many units they took during the week, he believed the horse-power they had developed had not yet been determined. Naturally in the first six months of the working of a new station the engineer had little time for testing, having to concentrate his attention upon the successful working of the station.

The superheaters (page 575) had been in use from the first start, and no trials had yet been made without them.

In reference to the remarks (page 578) as to the advantages of high tension over low, it was easy to make plausible statements as to the economy in mains which must result from using a small current at high tension to transmit the same energy as a large current at low tension; but in such statements the fact was lost sight of, that in all modern high-tension systems, whether alternating or direct current was used, the current was distributed by lowtension distributing mains, except in just such districts as were being supplied by high tension in Edinburgh, that is, where the houses were scattered. Thus the only saving to be obtained in mains by using a high-tension system was in the feeders, the distributing mains on both systems being the same size. The capital cost of the heary feeders on the low-tension system, which might, as in Edinburgh, be laid in a cheap form, had to be compared with the capital cost of the smaller but more highly insulated feeders, together with the cost of the transformer sub-stations, the transformers, and their switching gear. It would thus be seen that, as far as capital cost went, no one system could be said offhand to be better than any other for every town or district, but that every place had to be treated on its own merits. For Edinburgh six systems at least had 
been considered and worked out, each with equal care, before the particular system finally adopted was chosen as best fitting the circumstances.

As to the use of steel flanges on copper pipes (page 577), he had as yet had only six years' experience of them, and during this time had had no trouble with them.

With regard to vibration of the ring main of steam-pipes (page 577), he had had experience with several ring-mains constructed in identically the same way, and suspended in the same way, and little or no trouble had been met with from vibration. Although the ring main was slung on rods, or supported on roller brackets in some cases, it was held at a good many points, though not rigidly. In Edinburgh there were connections to eight engines, and two connections to the boiler-house main. Steam was not kept continuously in the pipes (page 587), but no trouble had yet been found from expansion and contraction of the pipes, either in Edinburgh or in other stations where similar rings had been used; the ring being held lightly at several points did not move bodily. He had himself seen a ring of steam-pipes which moved between two and three inches when the steam was first turned on; and that steam ring was running perfectly well now. No trouble had been found from the connections between the ring mains and the engines; in the Glasgow central station eleven engines had now been connected; the ring main was there held at a great many points, and as far as he knew no trouble had been experienced.

Provision had been made by means of doors at the side for cleaning out the feed-heater (page 589); and since it had been erected it had already been cleaned out. The cost of cleaning had been so small that he thought it had not affected the station costs.

If the station cost in Edinburgh was approaching pretty closely to the theoretical best (page 586), at any rate the figures given by Mr. Monkhouse were not the only ones, for he knew of another station, with an output of less than 4,000 units a week, at which the total works costs amounted to $0 \cdot 9 d$. per unit generated : so that, if this result was near the theoretically possible, it was also practically possible. 
The Prefionnt said that the matter of superheating was of course one of general engineering interest. The superheating arrangements in Edinburgh were not by any means finished, although the superheaters had been in use from the commencement. At first they had been so arranged as to have an undesirable tendency to superheat other things besides the steam; but this was being remedied, although even yet the superheating was not sufficiently complete. On 20th September, after he had had two or three days' working of the boilers, the actual evaporation per hour during a run of six hours was 8,130 lbs. in one boiler at an average pressure of 142 lbs. per square inch. The superheat however appeared to be only about $10^{\circ} \mathrm{Fahr}$. at the boiler, and there was no superhent at all at the engines. In the length of the superheater itself there was a drop of temperature from $738^{\circ}$ to $584^{\circ}$, that is, the gases had lost $154^{\circ}$ in passing through the superheater. The corresponding amount of heat was more than enough to superheat all the steam; unfortunately it did not yet appear to be sufficiently utilized. With the temperature of $738^{\circ}$ in the smoke-box end of the superheater, and $584^{\circ}$ in the back end, the temperature in the flue underneath the boiler, just going into the main flue, was $552^{\circ}$. On another day and with another boiler he had obtained results which did not differ much from these. The evaporation under these circumstances was remarkably good. The actual evaporation of water per pound of dry coal was $9 \cdot 1$ lbs.; or reduced to standard evaporation from and at $212^{\circ}, 9.55$ Ibs. The small coal used cost 78 . per ton; and the above evaporation was 73.4 per cent. of the theoretical or calorimetric value of the coal. As was well known, it was not easy to get so good an evaporation as this with small coal and with mechanical stoking. The rate of combustion was high, amounting to $55.8 \mathrm{lbs}$. of coal per square foot of grate surface per hour. (This was calculated on the actual moving grate-bar surface of 16 square feet per boiler. With Sinclair's grates there was in addition a large dead-plate, and also a certain space at the back end of the bars, on both of which no doubt combustion did actually go on.) The average amount of carbonic acid in the furnace gases was $9 \cdot 3$ per cent. by volume. In a trial made on the previous day there had been only $5 \cdot 7$ per cent. 
of carbonic acid with a combustion of only $45 \mathrm{lbs}$. of coal per square foot of grate per hour, and a boiler efficiency of only 69 per cent. By taking such steps as were indicated by these results, the higher figures already given were reached on the following day. From the superheaters he hoped to get good results, though naturally not so high as would have been obtained if he had gone to the extreme of putting the superheaters in a much hotter part of the furnaces. No doubt that would have been better for the sake of getting the heat; but he had felt a little hesitation about doing this, because the superheaters would then have been too much out of reach; in their present position on the top of the boilers the whole of the apparatus was entirely within reach. Any further results obtained in the course of the coming winter he would take care should certainly be published in some form, so that everybody could see them; because it was a matter in which engineers were all interested.*

The waste of heat iby radiation (page 578) was also a subject in which engineers were much interested; and they would lay to heart Mr. Geipel's statement that one square foot of bare steam-pipe surface radiated heat which was equivalent to half a ton of coal per annum, provided it was always in use. In an earlier stage of the Edinburgh station he had happened to meet with an interesting physical illustration, by which the radiation from the steam-pipe flanges could be shown. The pipes themselves had all been covered already, while their flanges had not jet been covered; there were arc lights in the station, and the shadows of the pipes and flanges were thrown on the wall. The shadows of the pipes were marked by perfectly quiet lines; but the shadows of the flanges were in a state of violent ebullition, which could be seen streaming upwards through a height of three or four feet. Obviously the air was set in rapid motion by the heat radiating from the flanges.

* Since the date of the discussion many other experiments have been made, and at the end of 1895 the amount of superheat in the steam in regular work is as much as $60^{\circ}$. Fahr., and often reaches $80^{\circ}$ Fahr., which appears a bighly satisfactory result. 
(The President.)

The capital costs (page 576) had not been given in the paper, but no doubt the author would add them. All the capital costs at the various electrical stations were of course published annually, and thus became public property. On looking at the capital costs of the various stations working on the various systems, he thought it would be found that there was not the least foundation for Mr. Geipel's suggestion (page 578) that high-tension work cost less per kilo-watt than low-tension; and he was rather surprised that this old fallacy should be brought up again, especially when it was so easy for everyone to see for himself what the actual facts were.

In regard to the suggestion (page 578) that larger units should be used, the primary object of all electrical stations was to run steadily and easily, and to make money. It had been found in many cases that running was neither so easy nor so profitable where the size of the units had been large. It seemed to be sometimes forgotten that even in the largest station there were hours when hardly so much as 100 H.P. was wanted. Moreover variation of load occurred not only every day, but to a still greater degree at different times of the year. In his own experience he had found that, even in large stations, the advantage of having small units was very great, always supposing the small units to be so arranged that they could be started and stopped with great convenience, and could be put into combination in any way required. It was no doubt a matter of opinion; but this was his own deliberate opinion after considerable experience in connection with various kinds of electrical work.

The author of the paper, though he had said so little about his own connection with this work, had in reality had a great deal to do with it from the commencement; and he was therefore specially glad that Mr. Burstall had been able to prepare the paper. It should also be mentioned that Mr. Monkhouse, who had come from Edinburgh expressly in order to attend the present discussion, was responsible for putting the whole station together, and more especially for carrying out the 24 miles of road work which had been completed before the station was opened. That work had been all carried out by himself and his own men, and at a cost which was remarkably reasonable, at any rate much lower than the lowest 
cost at which it would have been carried out otherwise. The work had turned out most satisfactorily; and he was glad to be able to congratulate Mr. Monkhouse not only on having carried it out in that way, but also on the really excellent figures which he had been able to present as the results of only six months' work under his charge. He now asked the Members to pass a vote of thanks to Mr. Burstall for his paper.

Mr. C. S. VEseY BRown, Borough Electrical Engineer of Sunderland, wrote that the town of Sunderland is similar to the city of Edinburgh in one respect, namely that the older and business part of the town is compact, and the residential district scattered. The systems of distribution adopted are similar to those in Edinburgh, namely low-tension three-wire for the business part of the town, and alternating high-tension for the suburbs. The adoption of these two systems combined is due to Professor Kennedy; and Sunderland was the first place, the writor believes, in which it was proposed to use the combination. There are three Lancashire boilers, $7 \frac{1}{2}$ feet diameter by 28 feet long, with additional steam-drums, made by Messrs. Hawksley, Wild and Co., of Sheffield, supplying steam for five sets of Willans engines and Holmes dynamos, three of which indicate 80 H.P. and the two others 40 H.P. each; these constitute the low-tension portion of the machinery. The high-tension portion consists at present of two sets of Crompton alternators, each of 38 kilowatts, driven by continuous-current motors There is also a set of Electric Power Storage accumulators, which enable the station to be supplied during the hours of light load with the boilers shut off. With the exception of the motor alternators, the station has much that is similar to an ordinary low-tension station. The ingenious arrangements of the battery-regulation and hospital-cell switchboards, used in Edinburgh, are in use here also, and are found to be all that can be desired; and though at first sight the switchboards appear complicated, yet the attendants have had no difficulty in learning and using the different connections on these boards; the chief usefulness of the hospital-cell switchboards 
(Mr. C. S. Vesey Brown.)

lies in the fact that the regulation can be effected on them without interfering with the main-battery switch. In the low-tension feeders there is about a quarter of a mile of copper strip, the rest being armoured rubber cable; and the network of mains is composed entirely of rubber cable, drawn into Doulton stone-ware casing under the footpath, and into cast-iron pipes under the roadway. The Doulton casing has proved a great success; it is about half the cost of cast-iron pipes equal in number to the ducts in the casing, and it is quickly laid; the only drawback is the difficulty at present of making it in longer lengths than three feet. The high-tension mains are of the British Insulated Wire Co.'s make, and are laid in the same manner as the low-tension mains, with the exception that where practicable stone-ware boxes have been used instead of brick boxes, the former being more quickly placed in position and less liable to leakage of water. Transformers are buried in the streets under the footpath, and are provided with high-tension switch and fuse; each transformer supplies its own little network at present, but eventually these smaller networks will be joined up, so as to supply all together and thereby equalize the pressure better.

Mr. Bunstall wrote that the capital expenditure on the work described in the paper has been as follows:-

Land and preliminary expenses . . . . . $£ 14,300$

Buildings . . . . . . . . . 18,000

Machinery and plant in station, arc-lamps, and lamp-posts . $\quad 34,600$

Mains and roadwork . . . . . . . 48,800

Total . . $\$ 115,700$

These figures are the actual sums expended, to the nearest $f 100$. It will be seen from them, and from the capacity of the plant in the station, that the capital cost per indicated horse-power installed is $£ 63 \cdot 6$, and per kilo-watt installed $£ 91 \cdot 1$. A comparison of these figures with the published capital costs of other installations in this country shows that, while the costs per kilo-watt installed in Edinburgh are slightly higher than the average of municipal installations of the same capacity, they are well below the average of 
the various companies. It is of interest to note that these published figures in no way bear out the statements sometimes made that the high-tension system is always cheaper than the low-tension; on the contrary, the average cost per kilo-watt installed is sensibly the same for installations on both systems.

An important point however in the design of the Edinburgh installation has been the provision in the first capital expenditure for future extensions; and this has made the capital cost for the first instalment of plant seem higher than it really is. Extensions, which will nearly double the capacity of the station and mains, are now being proceeded with; and the cost of these extensions will not exceed $£ 30,000$, which will make a total capital cost of about $£ 146,000$. The capital cost per kilo-watt installed will be brought to about $£ 58$, which is much lower than the arerage for even municipal installations.

In regard to the actual total cost of the feeders, he had found that, owing to the fact that the feeders in many places were laid at the same time as the distributing mains, it was difficult to separate the sums paid in roadwork and jointing for the two together. The cost of armoured cable and copper strip for the feeders was in round figures $£ 8,500$, or only about $7 \cdot 4$ per cent. of the total cost; and any saving to be obtained by using high tension could be made only on this amount. The cost of a system of high-tension feeders with their transformers, sub-stations \&c., would have been closely the same as that paid for the low-tension feeders; but the roadwork would have been somewhat less for the former, because plain trenches would have been used instead of culverts in a good many places. If the capitalised value of the rent of sub-stations and of the wages of men for switching the transformers on and off were added to the other costs, the high-tension feeders would hava actually cost more than the low-tension. This would be entirely different if the site of the central station had been far away from the centre of the city, and if the feeders had had to be made considerably longer.

As to the efficiency of the motor-driven pumps (page 574), subsequently to the discussion on the paper Mr. Monkhouse had made a test of the pumps, and had found that, with the pumps

3 c 2 
(Mr. Burstall.)

running at one-third of full load, the combined efficiency of the motor and pump was about 49 per cent., 2.66 units being used per thousand gallons pumped against $150 \mathrm{lbs}$. pressure per square inch.

He was sorry that, through his fault, a misunderstanding had arisen as to the periodicity at which the alternators would be worked. The figure given in the paper, $52 \frac{1}{2}$ complete alternations per second (page 565), was the periodicity attained when the engines at present in the station were run at their nominal full speed; but as soon as any additional plant was put into the high-tension section, the present engines would be run slightly below their full speed, and the whole of the alternators would run at a periodicity of 50 complete alternations per second, which was the specified periodicity, and that for which all the instruments, transformers \&c., were designed. He doubted however whether such an alteration made any real difference in the design of transformers. 
है

EDINBURGH ELECTRIC LIGHTING.
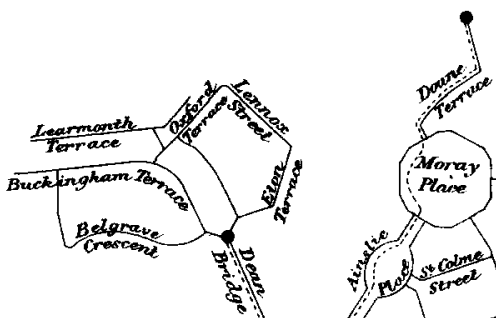

calton

Hill

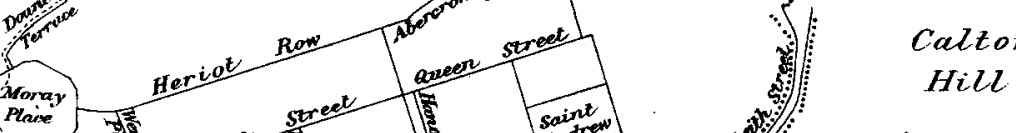

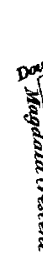

\section{Mains}

Feeders

Feeding Points

High-Tension Arc Lighting

Low-Tension Arc Lighting

Scale 1,500 feet to an inch
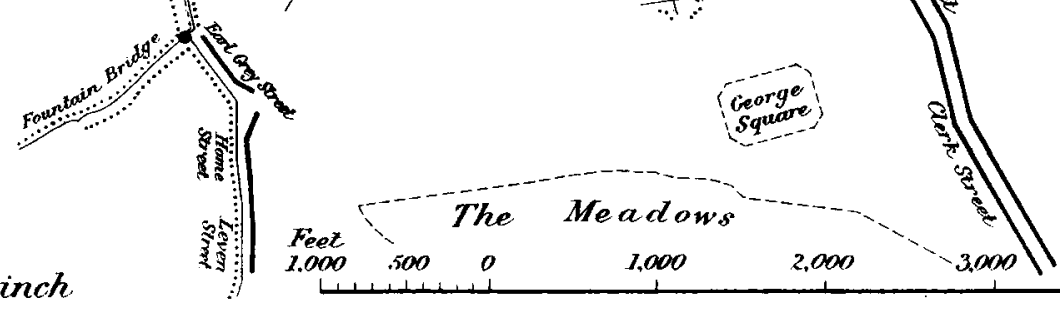

Fig. 1 .

Plan of Mains.
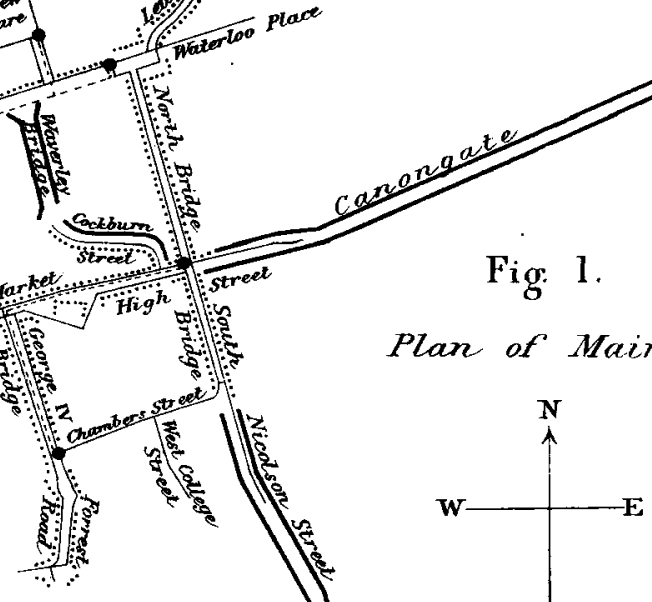


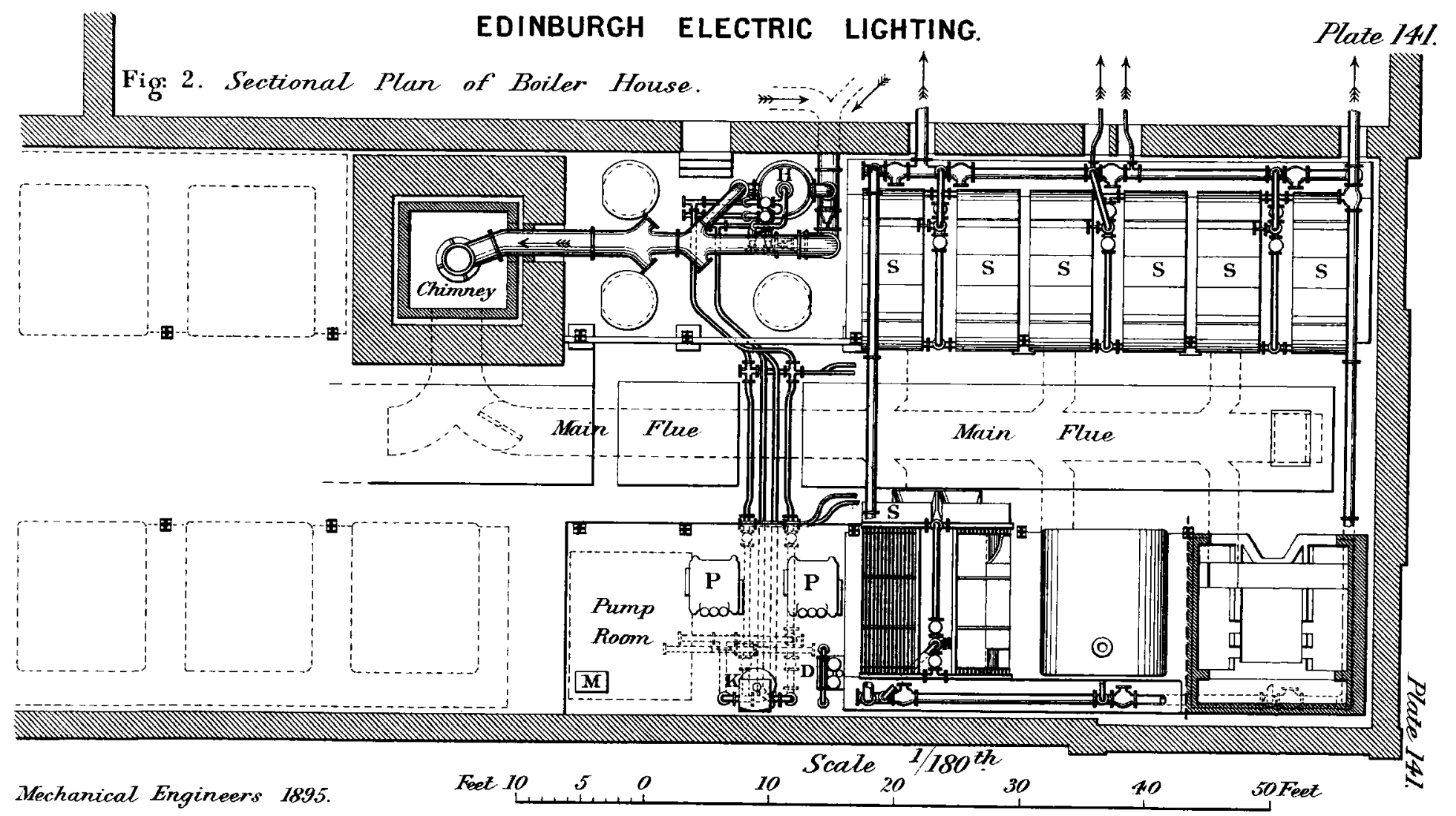




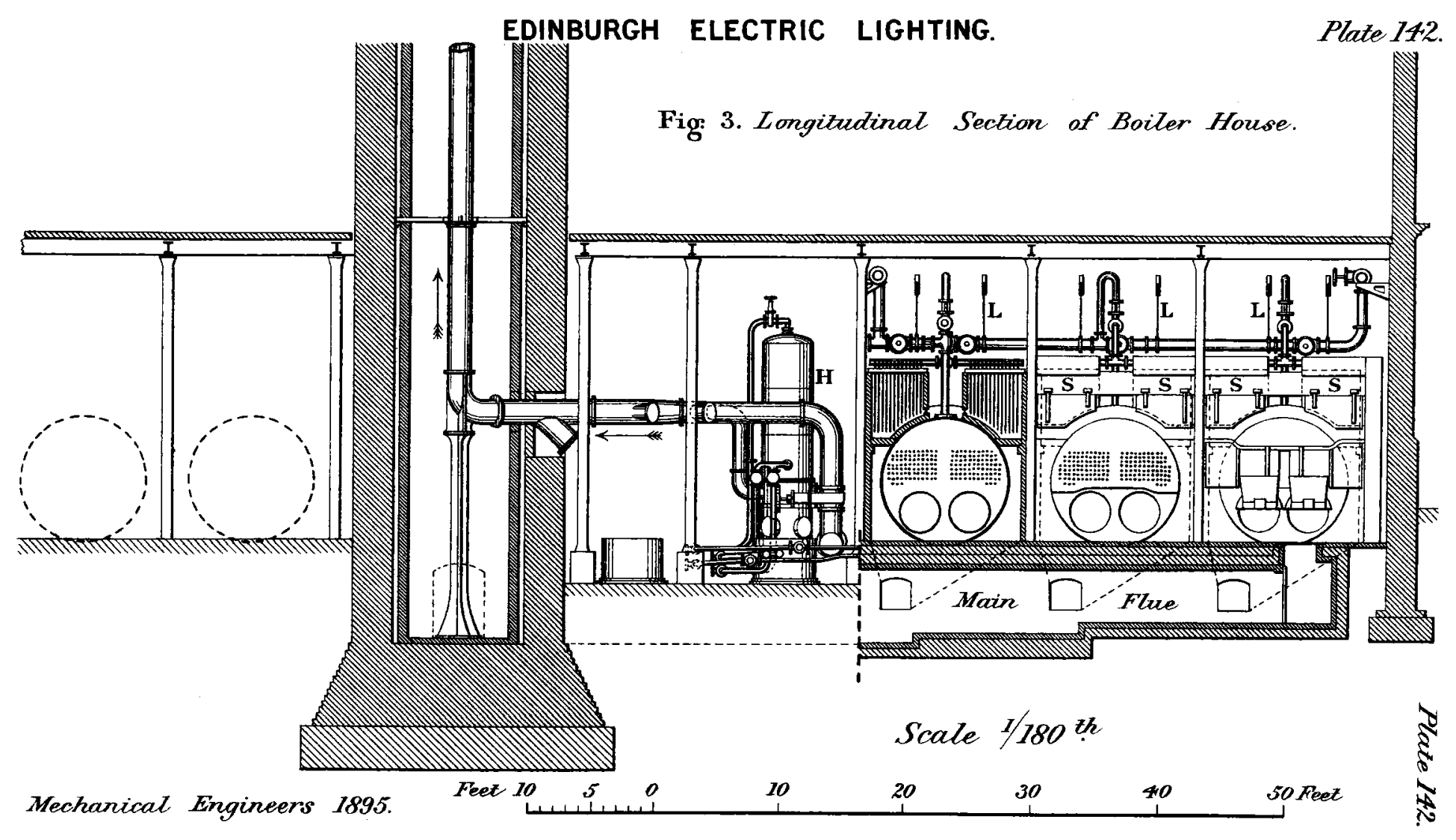




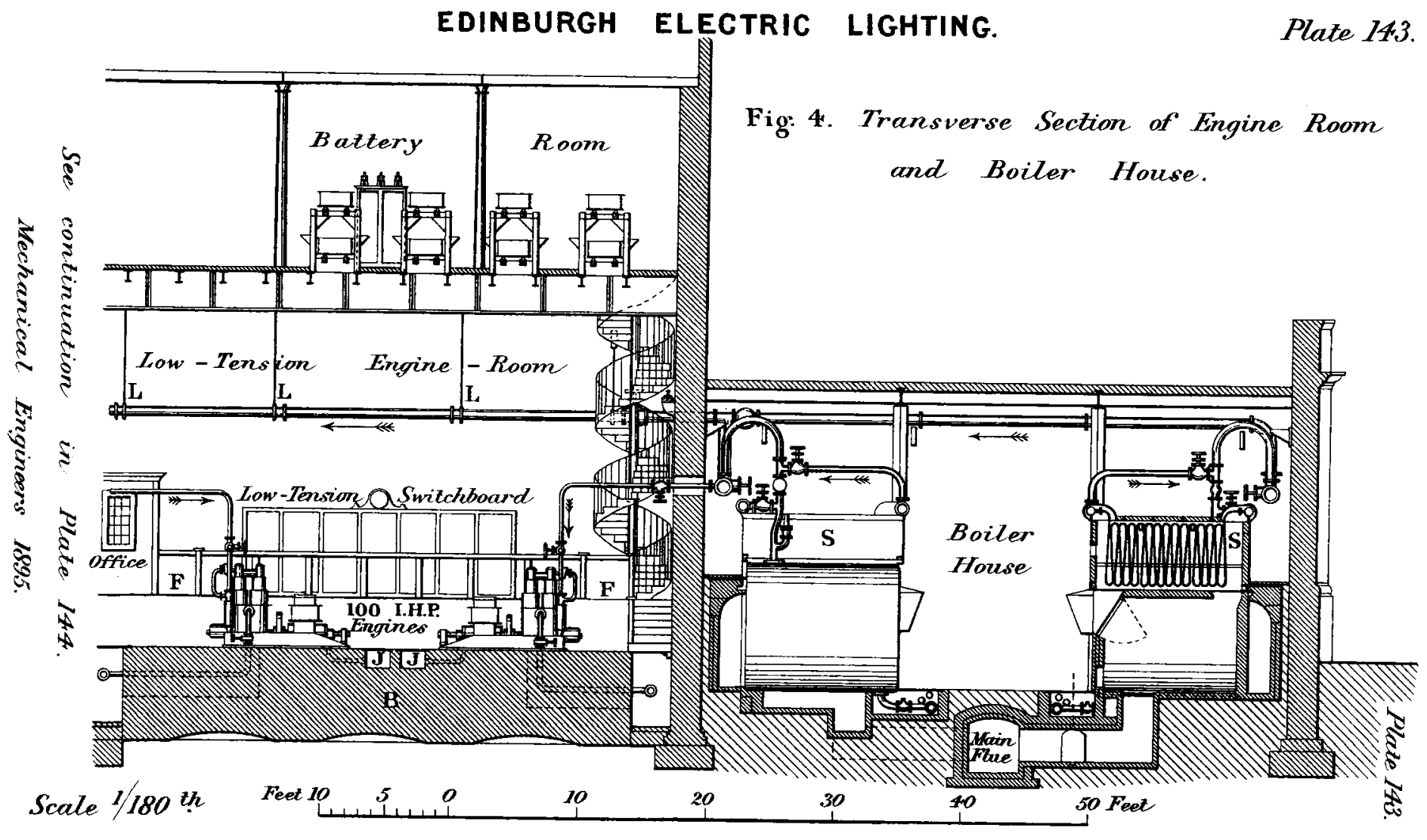




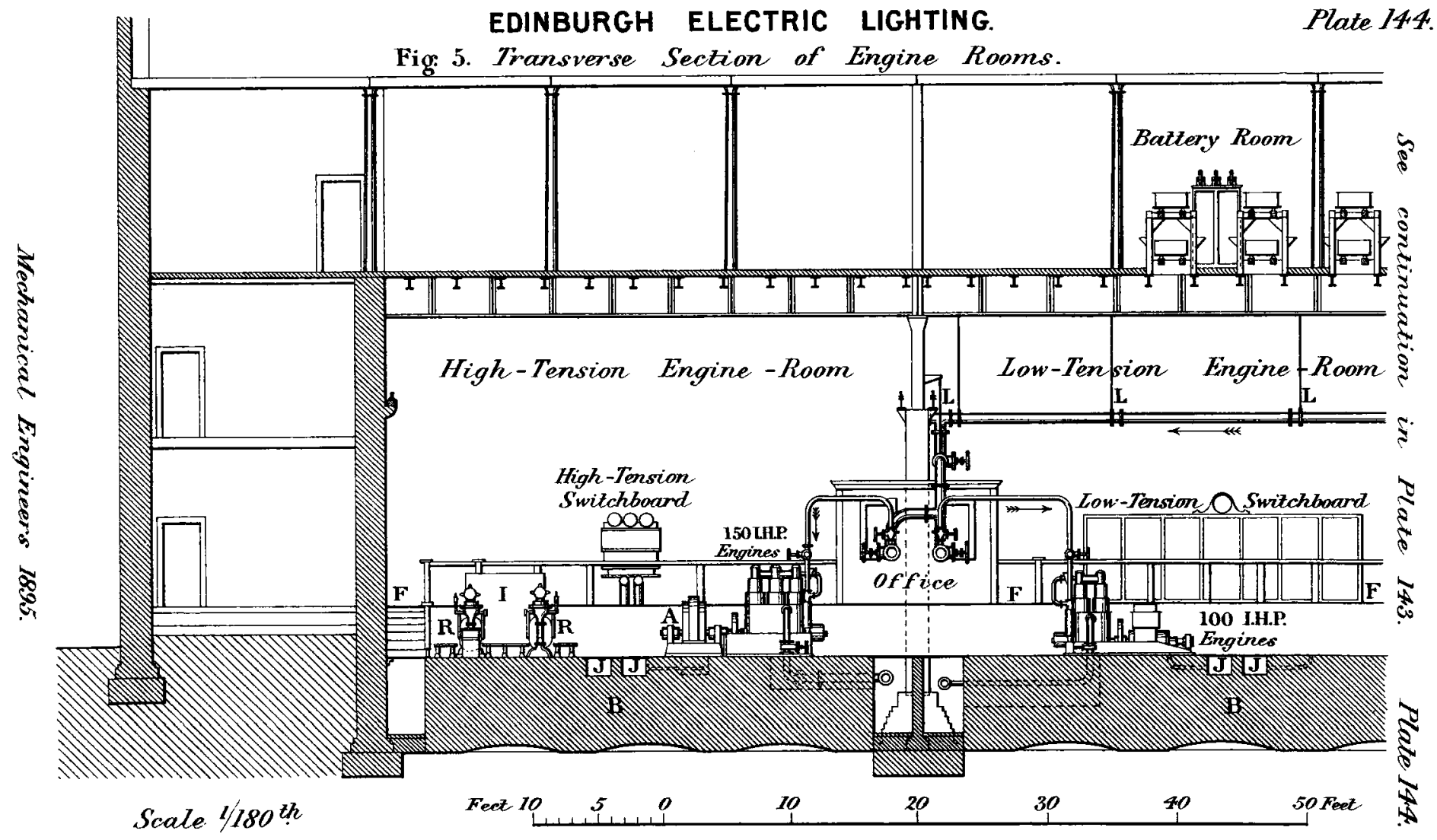




\section{EDINBURGH ELECTRIC}

L IG H T IN G.

Plate 145.

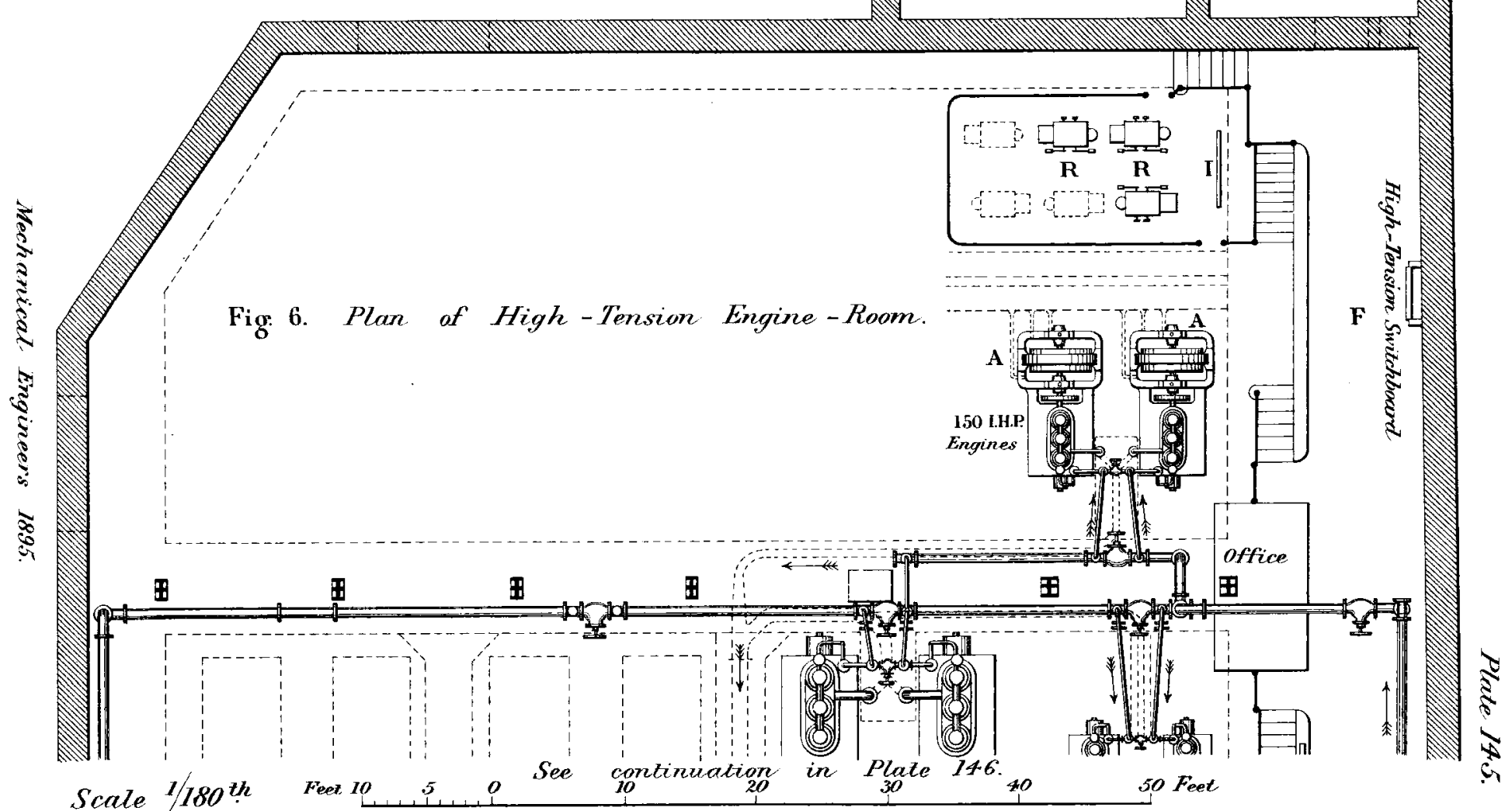




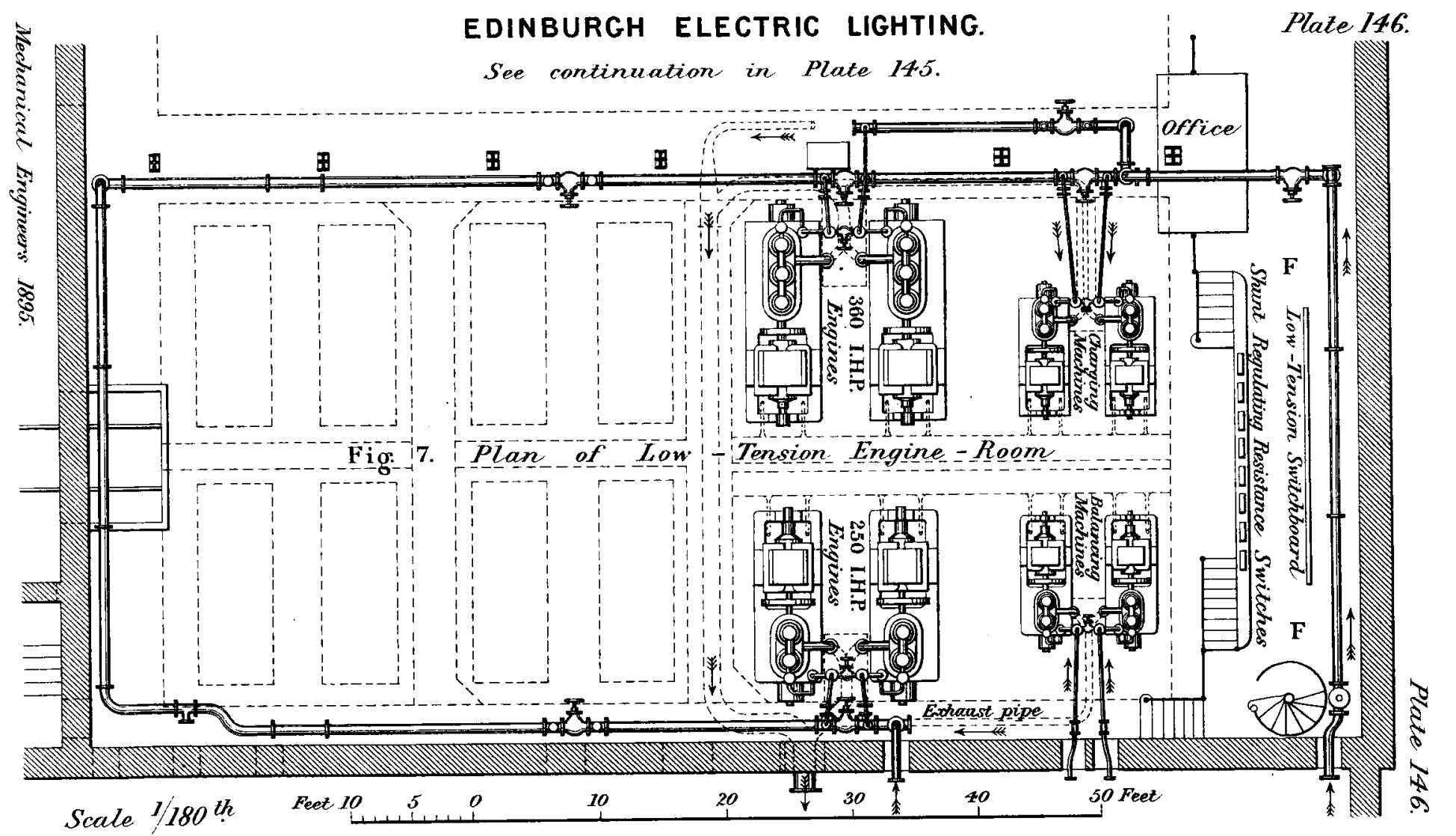




\section{EDINBURGH ELECTRIC LIGHTING.}

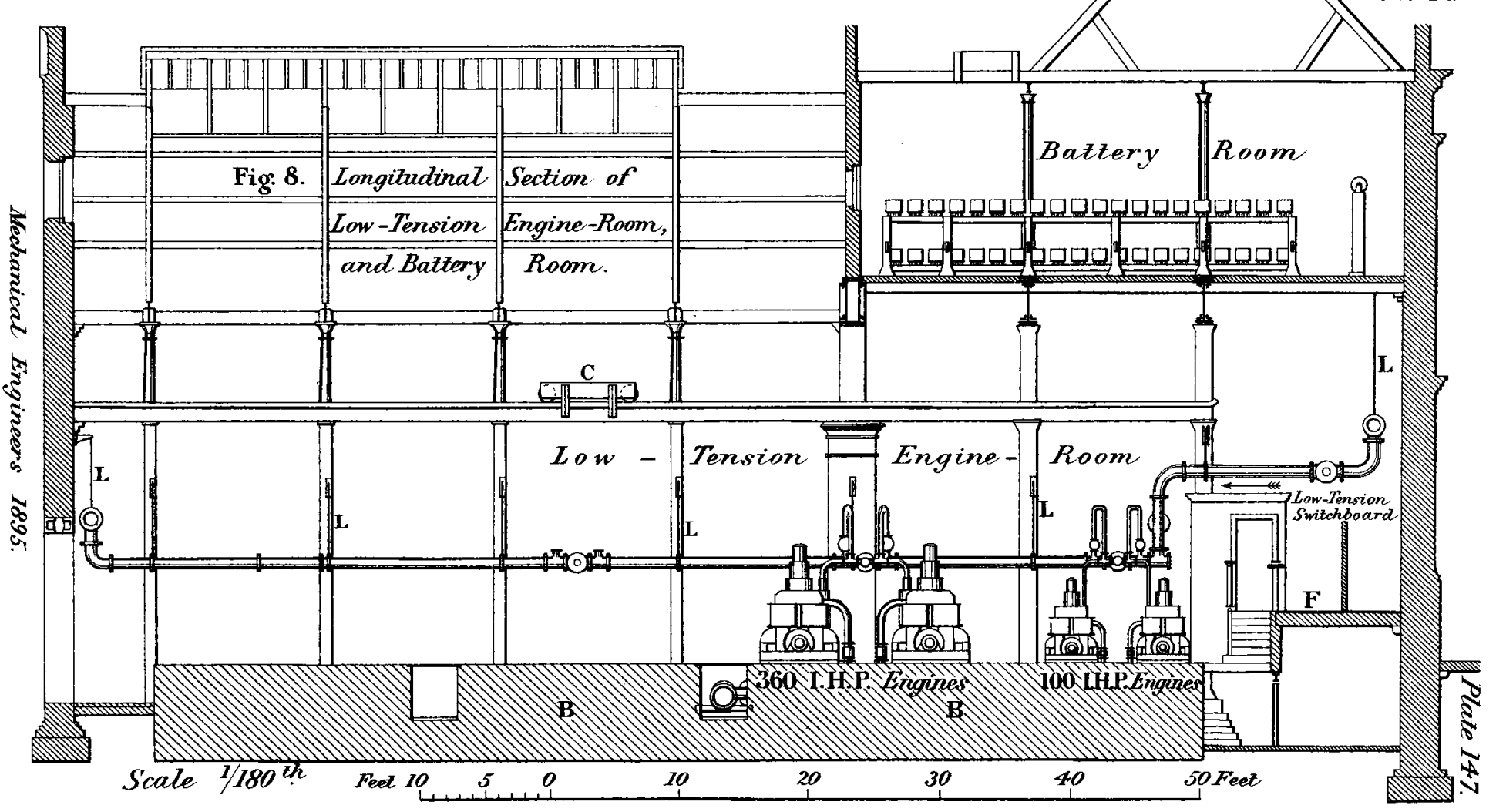


EDIN BUR GH

Fig. 9. Switchboard connections.

\section{Positive.}

Negative

Middle Wire

Positive or Negative according to position

है

8
ELECTRIC LIGHTING.

Plate 148.

ODynamo

Q Voltmeter

Q Ammeter

(1) Polarised Ammeter

曰Automatic Gut-out \& Fuse

of Duplex Fuse

$\triangle$ Reversible Ampere-hour Weter

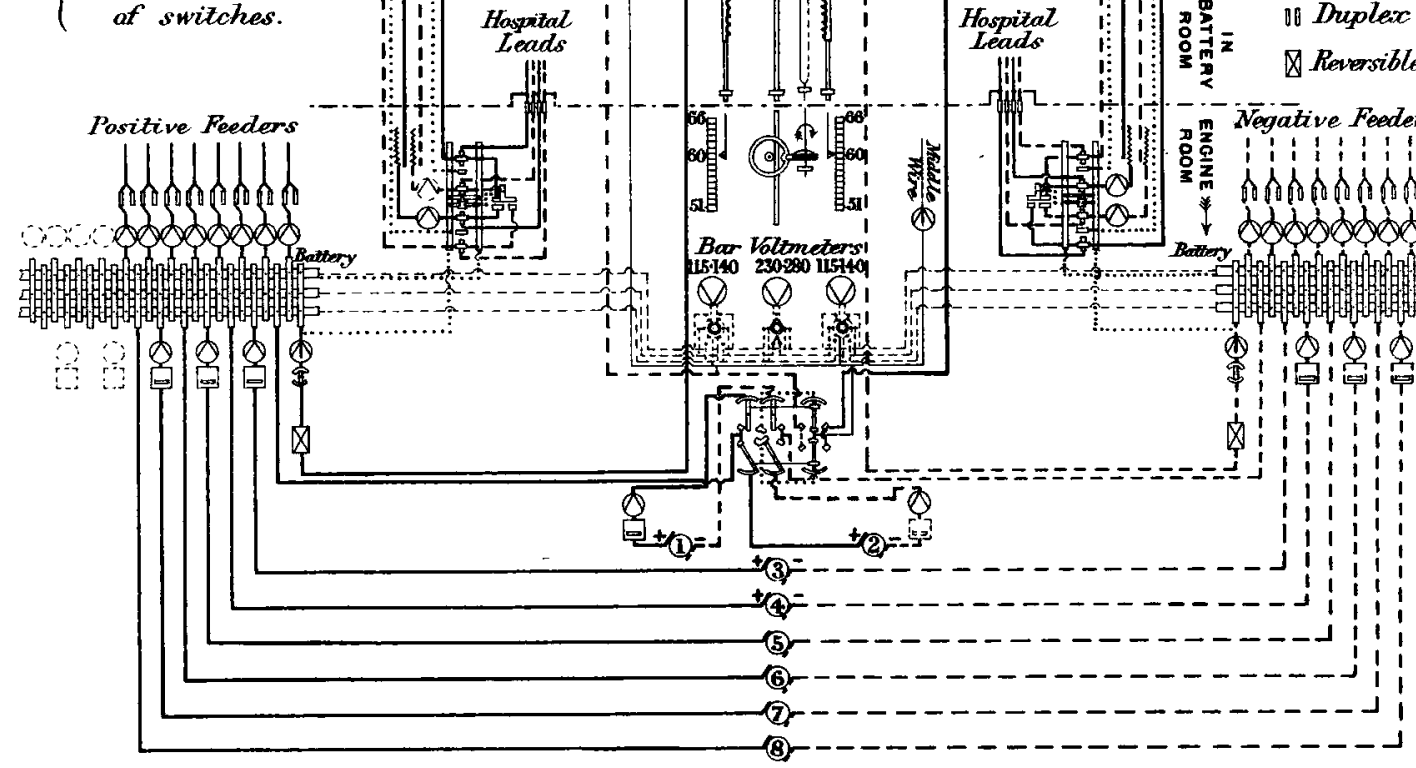


EDINBURGH ELECTRIC LIGHTING. Plate 149. Distributing Mains in Junction-Box.

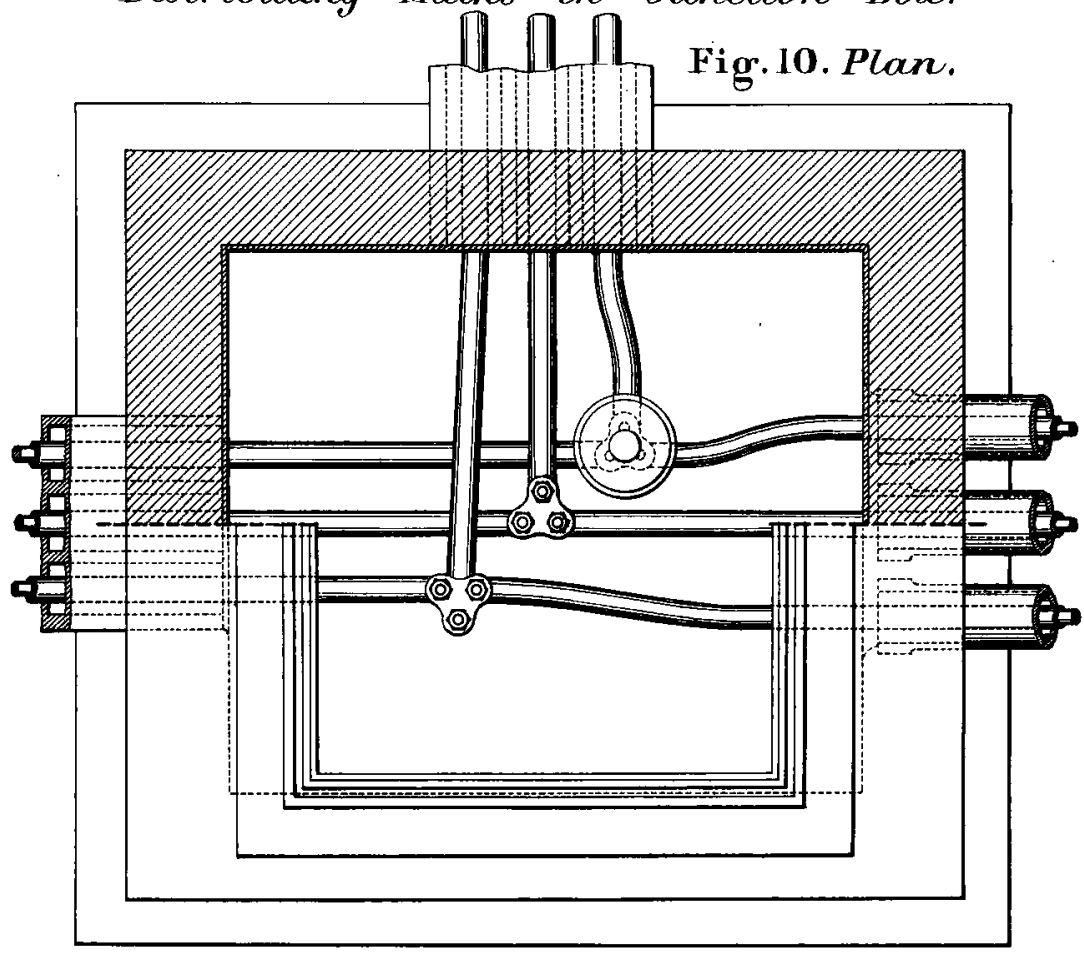

Fig. II. Vertical Section.

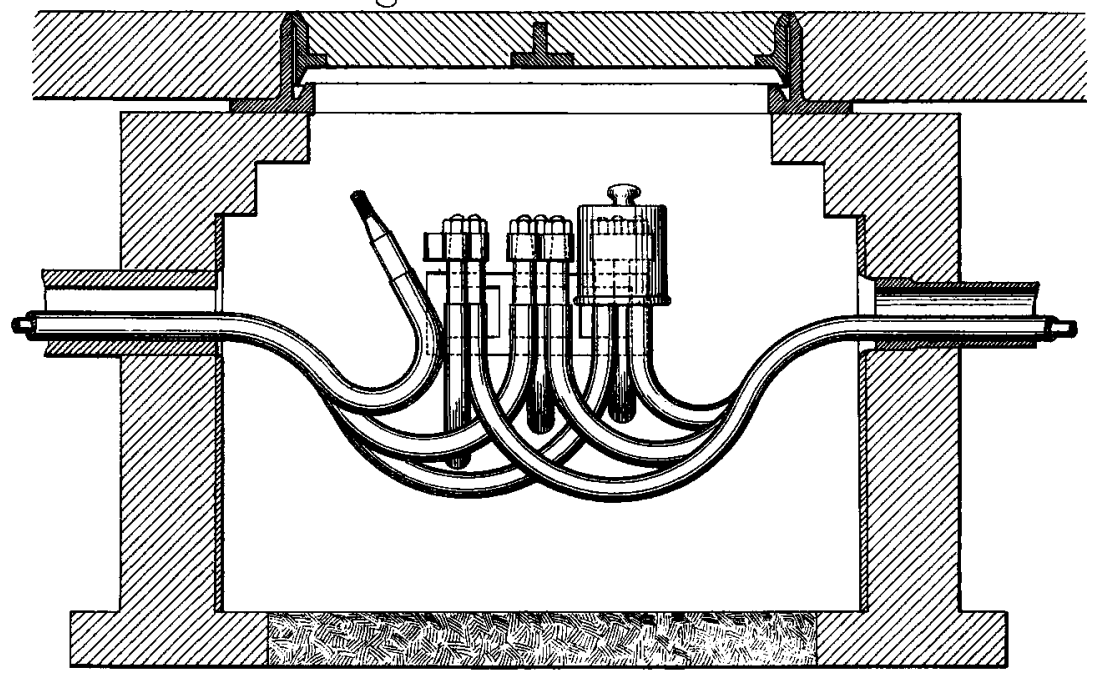

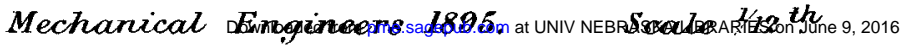


EDINBURGH ELECTRIC LIGHTING. Plate 150.

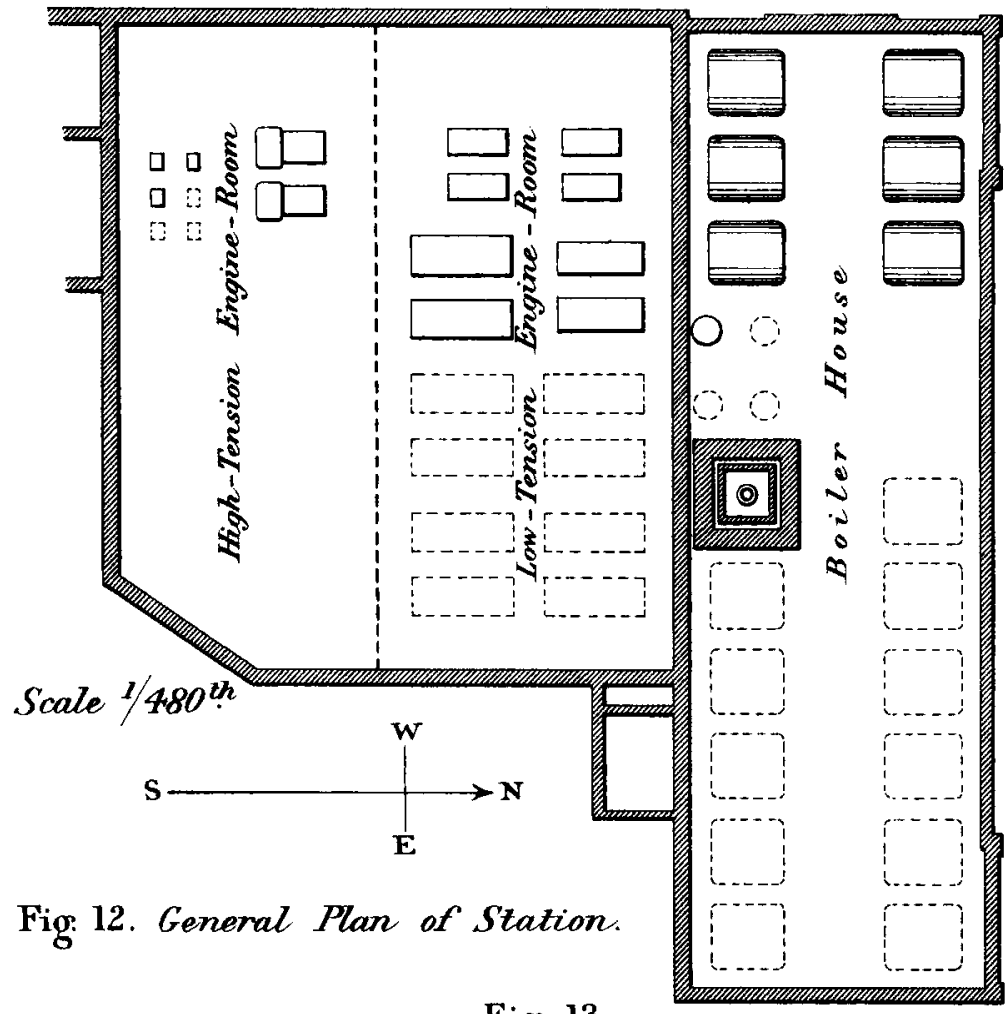

Fig: 13.
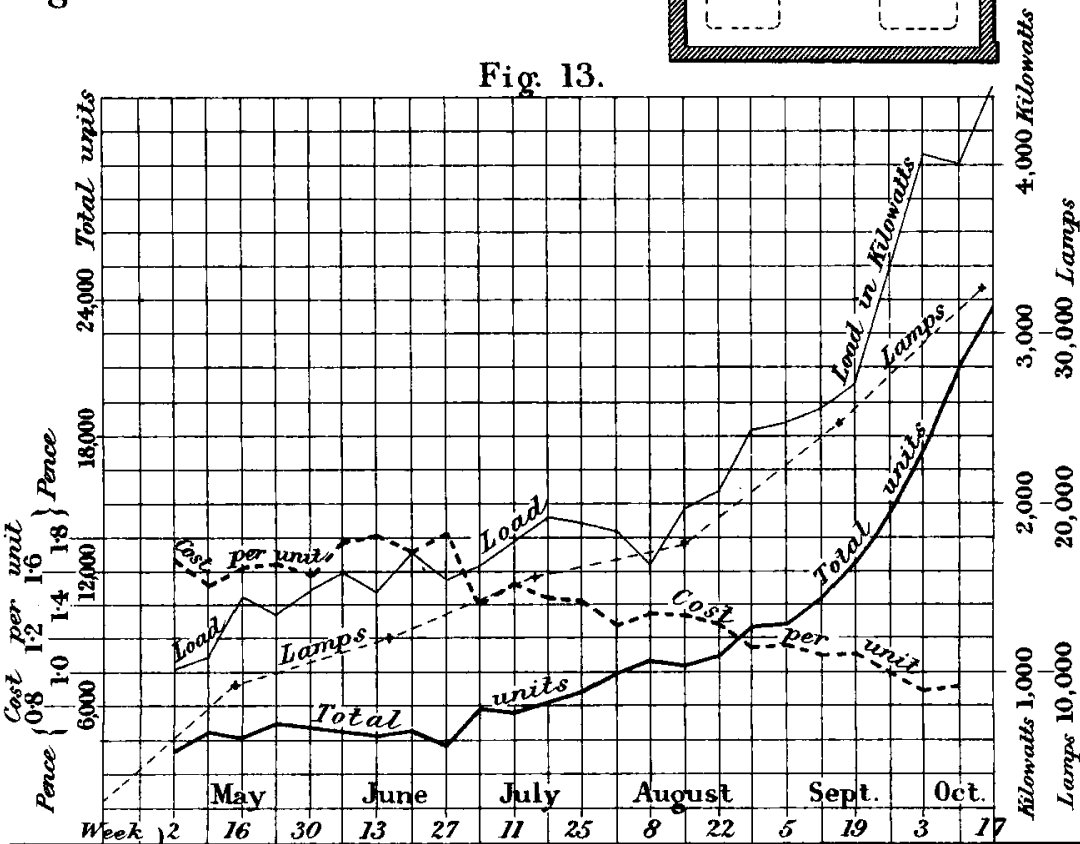

8
8
8
용
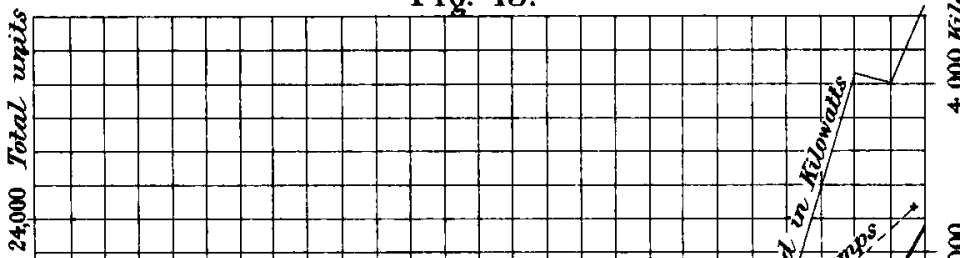

5

8 